\title{
Joergensenella, a new subgenus of Neotropical Megachile (Hymenoptera: Megachilidae), with a key to Argentinean Megachile with specialized facial pollen-harvesting hairs
}

\author{
Arturo ROIG-ALSINA \\ Museo Argentino de Ciencias Naturales "Bernardino Rivadavia”, Av. Angel Gallardo 470, 1405 Buenos Aires, \\ Argentina. Email: arturo@macn.gov.ar
}

\begin{abstract}
A new subgenus of Megachile, Joergensenella $\mathrm{n}$. subg., is described for the Neotropical Region. It is distributed in Argentina, southern Brazil, and Uruguay. Males run to Chrysosarus in available keys to subgenera of Megachile, and have been included as such in recent catalogs, while the females run in the keys, and have been included in catalogs, as Dasymegachile or Cressoniella. Association of sexes for all the species are presented for the first time. Besides the type species, $M$. joergenseni Friese, the following are included in the subgenus Joergensenella: M. bruneriella Cockerell, M. una Vachal, M. lujanense n. sp. (from Mendoza, Argentina), M. fidalgoi n. sp. (from Jujuy, Argentina), M. puntana n. sp. (from San Luis and Tucumán, Argentina), and M. yana n. sp. (from La Rioja, Argentina). Females of one of the species included, M. (Joergensenella) una, bear specialized hairs on the face for the collection of pollen from nototribic flowers. A key is presented to separate this species from other two Megachile in Argentina with a similar specialization: M. (Dasymegachile) schwimmeri Engel, and M. (Cressoniella) boliviensis Friese.
\end{abstract}

Key words: Megachile, leafcutter bees, new subgenus, facial pollen-collecting apparatus.

Resumen: Se describe un nuevo subgénero de Megachile de la Región Neotropical, distribuido en Argentina, sur de Brasil y Uruguay. Los machos de Joergensenella $\mathrm{n}$. subg. van a Chrysosarus en las claves disponibles de subgéneros de Megachile, y han sido incluidos como tales en catálogos recientes, en tanto que las hembras van en las claves, y han sido incluidas en los catálogos, como Dasymegachile o Cressoniella. Se asocian los sexos de todas las especies por primera vez. Además de la especie tipo, M. joergenseni Friese, se incluyen las siguientes especies en el subgénero Joergensenella: M. bruneriella Cockerell, M. una Vachal, M. lujanense n. sp. de Mendoza, Argentina, M. fidalgoi n. sp. de Jujuy, Argentina, M. puntana n. sp., de San Luis y Tucumán, Argentina, y M. yana n. sp. de La Rioja, Argentina. Las hembras de una de las especies incluidas, M. (Joergensenella) una, tienen pelos especializados en la cara para la recolección de polen de flores nototríbicas. Se presenta una clave para separar esta especie de otras dos Megachile de la Argentina que presentan una especialización similar: M. (Dasymegachile) schwimmeri Engel, y M. (Cressoniella) boliviensis Friese.

Palabras clave: Megachile, abejas cortadoras de hojas, nuevo subgénero, aparato facial colector de polen.

\section{INTRODUCTION}

The genus Megachile Latreille is the largest genus of bees in the Neotropical Region, with over 400 valid species recognized at present (Raw, 2007, Moure et al., 2007, Asher \& Pickering, 2018). The scope of this genus of worldwide distribution has varied depending on the inclusion or not of those groups that construct their nests with mud or resin together with the leafcutter bees (Michener, 2007). The recognition of a single genus for this enormous complex, as proposed by Michener (2007), is a taxonomic prob- lem on which bee researchers have not reached agreement to date (Trunz et al., 2016; González et al. 2019). The monophyly of the group of subgenera that includes all leafcutter species, i.e. Megachile in a strict sense, is supported by these recent studies. The large South American fauna of Megachile is composed nearly exclusively of leafcutter species, with the single exception of the subgenus Chelostomoides Robertson, which reaches southwards to Argentina (Roig-Alsina, 2019).

The subgeneric classification of Megachile in the Neotropics was built by Mitchell (1934, 1943, 
1980), and revised by Michener (2000), who recognized 27 valid subgenera in the region. Later additions of new subgenera were made by Raw (2006) and González et al. (2018). In spite of the large number of subgenera recognized for the Neotropical fauna, the present subgeneric classification remains unsatisfactory, with a number of species which cannot be ascribed to a subgenus in the current subgeneric system. González et al. (2018) have underlined the problems of this classification in their recent revision of the subgenera Zonomegachile Mitchell and Rhysomegachile Mitchell. One important setback in the understanding of the Neotropical fauna is the lack of association of sexes for a vast number of species. This is the case for $M$. joergenseni Friese and related species, which have not been recognized as a distinct lineage. The males of this group run to Chrysosarus Mitchell in available keys to subgenera of Megachile, while the females run in the keys, and have been included in catalogs, as Dasymegachile Mitchell or Cressoniella Mitchell. The purpose of the present contribution is to present the association of sexes for all the species in the group, and to characterize it as a new subgenus.

Females of one species in the new subgenus bear specialized facial hairs on the clypeus and the supraclypeal area for the collection of pollen from nototribic flowers, a specialization that has been described in detail for species in the European fauna (Müller, 1996a, 1996b). A key is presented to separate this species from other two Megachile that have a similar specialization in Argentina.

\section{MATERIAL AND METHODS}

Terminology for structures follows Michener (2007). The following abbreviations are used: UID, upper interocular distance, LID, lower interocular distance, PD, puncture diameter. The maximum diameter of the median ocellus (MOD) is used as a reference to express the length of the pubescence and other structures. The metasomal terga $(\mathrm{T})$ and sterna $(\mathrm{S})$ are identified with Arabic numerals. In the lists of material studied $\mathrm{F}$ stands for female, and $\mathrm{M}$ for male. The specimens studied are deposited in the following institutions: Facultad de Agronomía, Universidad de Buenos Aires (FAUBA), Instituto Argentino de Investigación de Zonas Áridas, Mendoza (IADIZA), Museo Argentino de Ciencias Naturales, Buenos Aires (MACN), Museo de La Plata, La Plata (MLP), Natural History Museum,
London (NHMUK), and Snow Entomological Collection, Lawrence, Kansas (SEMC).

\section{RESULTS}

\section{Genus Megachile Latreille Joergensenella new subgenus}

urn:lsid:zoobank.org:act:AF5B57CA-4174-44C28468-C17D3A20A224

Type species: Megachile joergenseni Friese, 1908

Description. Bees 6.5-14.0 mm long; from entirely black to pale haired with distinct metasomal apical bands. In three out of the seven included species the scopa is black. Female. Mandible with four teeth, with incomplete cutting edge in second interspace and complete cutting edge in third interspace; apical tooth not broader than second or third; fourth tooth acute. Mandible flattened, with space between distal margin and cutting edges narrow; with outstandingly developed brushes of setae on distal end of acetabular and outer grooves (Fig 2C); condylar groove also with distal brush. Clypeus usually regularly convex, except in one species (M. una) weakly convex, bearing specialized, bent hairs; apical margin with median denticle. First flagellomere 1.2-1.4x as long as apical width; longer (1.1-1.4x) than second. Preoccipital margin of head narrowly rounded behind vertex, rounded behind gena. Lateral ocellus nearer to posterior margin of vertex than to eye. Claws with basal seta short and spiniform. Metasoma ovoid, T2 broader than either T1 or T3. T6 with conspicuous erect hairs, slightly concave in profile, and with rounded apex in dorsal view. Metasomal sterna without apical hair fasciae beneath scopa. S6 without bare apical lip, uniformly covered with scopal hairs, except one species (M. una) with median preapical area bare to clothed with few sparse hairs. Male. Mandible tridentate, without basal projection, but lower margin forming preapical angle (absent in $M$. una). First flagellomere 1.1-1.4x as long as apical width; shorter (0.7$0.8 \mathrm{x}$ ) than second. Hypostomal area pilose and unmodified. Forecoxa with spine 1.0-1.3x MOD; basad to spine with group of stiff bristles more or less hidden by long plumose hairs. Foretarsus slender to moderately enlarged, with distinct outer fringe. Middle tibial spur present, articulated to tibia. Posterior femur without specialized, longitudinal patch of short hairs on inner dosolateral surface. Metasoma with four exposed 
sterna. Preapical carina of T6 with median emargination; apical margin of $\mathrm{T} 6$ with small lateral tooth and triangular to rounded paramedian projection. Antecosta of S5 with median projection directed apically, bearing tiny spicules. S8 without marginal hairs.

Etymology. The new subgenus is named after Peter Jörgensen, a Danish entomologist that greatly contributed to the knowledge of the bee fauna of Argentina at the beginning of the 20th century.

Comments. The distinctiveness of Joergensenella has not been recognized to date most probably because of the lack of association of the sexes. Females most resemble species of Dasymegachile or Cressoniella, although they do not agree with all the features of these subgenera, while the males can be easily confused as species of Chrysosarus. As a matter of fact, the type species of the new subgenus, $M$. joergensen $i$ with its synonym $M$. atramentata (both names based on females only), has been treated either as Dasymegachile or Cressoniella (Raw, 2002, Durante \& Abrahamovich, 2006; Raw, 2007; Ascher \& Pickering, 2018).

It is difficult to define Joergensenella by unique apomorphies, as is true for most subgenera of Megachile, but the outstandingly developed apical brushes of the female mandible may constitute one such feature (Figs. 2C, 9, arrow). Similar brushes, although less developed, are present in Austromegachile, Tylomegachile and Cressoniella.

Another feature of interest in species of Joergensenella is the spiculate median projection of the antecosta of the male S5 (Figs. 6-8). A median projection of the antecosta of S5 is present among Neotropical subgenera only in Cressoniella and Zonomegachile, although the projection is not spiculate. Among Nearctic subgenera a projection is present in the species included by Mitchell in Derotropis, and in a few species of Xeromegachile, although in the latter the projection is spiniform (Mitchell, 1936, 1937). Given the importance of mandibular structure in the definition of subgenera and in the construction of keys to subgenera of Megachile, it is of interest to clarify the differences between Joergensenella, Dasymegachile, and Cressoniella. The interpretation of the dentition of the female mandible of Dasymegachile has been confusing and misleading. Mitchell (1943), in his key to subgenera of Neotropical Megachile, charac- terized his new subgenus Dasymegachile by an acute upper tooth of the mandible. His figure 10 (1943, p. 661) portraying the mandible of $M$. saulcyi Guérin (type species of Dasymegachile) with an acute upper tooth is incorrect and it may have been based on a worn specimen. Later he presented (Mitchell, 1980) an accurate drawing of the mandible of $M$. saulcyi (p. 63, figure 44) with an incised upper tooth. Nevertheless, in his key on page thirteen (Mitchell, 1980) he indicated that Dasymegachile has an acute upper tooth, and mentioned this condition in Dasymegachile as an exception to the subgenera that he grouped under Cressoniella (treated as a genus), all with a blunt or truncate upper tooth. Michener (2000, 2007), in his key to subgenera of the Western Hemisphere, as well as in the text on Dasymegachile, also indicates that the upper tooth is acute in this subgenus. This problem has been partly amended in the new key to subgenera presented by González et al. (2018), where Dasymegachile appears twice in the key, either with an acute or with a broad fourth tooth. Nevertheless, all the species of Dasymegachile that I have been able to examine (some 25 species) have a broad upper tooth, either truncate or incised, and none will run to their couplet 27 (González et al., 2018). Joergensenella can be separated from Dasymegachile by the acute upper tooth in all included species.

The subgenera Cressoniella and Joergensenella both have the female mandible with a complete cutting edge in the third interspace and an incomplete one in the second interspace, but in Cressoniella the fourth tooth is truncate or incised, and the apical brushes of the mandible are moderate and restricted to the distal end of the acetabular groove, without brushes on the outer or condylar grooves. Males of the two subgenera are quite different, those of Cressoniella with four-toothed mandibles, without forecoxal spines, and the preapical carina of $\mathrm{T} 6$ with a pair of acute teeth.

In the key to subgenera of Megachile of the Western Hemisphere presented by González et al. (2018), females of Joergensenella would run to couplet 27 , together with those subgenera having cutting edges in the second and third interspaces, S6 without a bare apical rim, mandible with apical tooth not broader than second or third tooth, metasomal sterna with ordinary setae, without entire apical fasciae beneath S2-S4, a four-toothed mandible with the upper tooth acute or right-angular, and an ovoid metasoma. Couplets 27-28 can be modified as follows to include Joergensenella: 
27(26). Cutting edge in third interspace incomplete. Sterna with apical fasciae beneath scopa, laterally on S2-S4, along entire margin on S5. (South America).Zonomegachile Mitchell

- Third interspace with complete cutting edge. Sterna without apical fasciae beneath scopa.

28

28(27). Apical margin of clypeus medially straight, polished, without denticles. Outer surface of mandible clothed with white hairs. (Nearctic)

Litomegachile

- Apical margin of clypeus with median denticle, and denticulate to crenulate on each side of middle. Outer surface of mandible clothed with black hairs. (South America)

Joergensenella

All males of Joergensenella will run to Chrysosarus in Michener (2007) or in González et al. (2018) keys. In the key of González et al. (2018) males of $M$. una will run to couplet 20 (since the mandible lacks an inferior angle or projection), while the other species will run to couplet 35 (since an inferior angle on the mandible is present). In all cases males of Joergensenella can be separated from males of Chrysosarus (in a broad sense, including Dactylomegachile Mitchell, Austrosarus Raw, and several problematic taxa) by the lack of a specialized, longitudinal patch of short hairs on the inner dorsolateral surface of the hind femur.

\section{Key to species of Joergensenella}

\section{FEMALES}

1.- Metasoma with white hairs entirely covering T1-T3 and black hairs on T4-T6 (Fig. 1C). Vertex of head very narrow, distance between lateral ocellus and occipital margin of head 1.2x MOD. Scopa black (Fig. 1C). M. fidalgoi

-- Metasomal terga with pubescence entirely black, or with apical pale bands (at least laterally) on T2-T5. Vertex of head broader, distance between lateral ocellus and occipital margin of head 1.5-2.0x MOD. Color of scopa variable.

2.- Mesosoma and metasomal terga with pubescence black. 3

-- Mesosoma, at least on scutum laterally, with pale hairs; metasomal terga with pale apical bands.

3.- Scopa orange, at least on S3-S5 (Fig. 1E). T3$\mathrm{T} 4$ with black plumose hairs of apical bands restricted to sides; hairs of T3-T4 medially stiff and simple. M. lujanense

.- Scopa black. T3-T4 with plumose hairs forming entire black apical bands, distinct medially (Figs. 2A-B, 5E). 4

4.- Anterior tibial spur with pointed apex, concolorous with remainder of spur (Fig. $4 \mathrm{H}$ ). Clypeus with median longitudinal impunctate band (Fig. 2C). Outer surface of mandible polished (Fig. 2C). ........... . joergenseni

-- Apex of anterior tibial spur blunt, blackened (Fig. 4J). Clypeus uniformly punctate. Outer surface of mandible weakly tessellate.

M. yana

5.- Clypeus and supraclypeal area with specialized hairs; those on the clypeus with apices sharply bent down and those on the supraclypeal area with wavy apices (Fig. 9). Supraclypeal area with impunctate transverse band above epistomal suture (Fig. 9). M. una

-- Clypeus and supraclypeal area with straight to gently curved hairs. Punctation of supraclypeal area reaching epistomal suture. ...... 6

6. Vertex narrow, distance from lateral ocellus to posterior margin of head 1.5x MOD. T6 with erect black hairs and dark brown to black decumbent hairs (Fig. 5A). M. puntana

. Vertex broad, distance from lateral ocellus to posterior margin of head 2x MOD. T6 with golden yellow erect hairs and yellowish decumbent hairs (Fig. 1A). M. bruneriella

\section{MALES}

1.- Forebasitarsus yellow, flattened, 2.3-2.6x as long as its apical width, with dense outer fringe of evenly long hairs (Figs. 3F-G, 3H-I). Anterior tibial spur truncate, thickened and blackened at distal end of velum (as in Figs. 4I-J). Under surface of anterior basitarsus without spots, or with dark brown spot both on basitarsus and on second tarsomere. ..... 2

-- Forebasitarsus dorsally black, rather cylindrical, 3.1-3.4x as long as its apical width, with outer fringe of short hairs interspersed with longer hairs (Figs. 3A-E). Anterior tibial spur with usual apex beyond distal end of velum (as in Fig. 4H). Under surface of forebasitarsus with black spot on second tarsomere. ... 3

2.- Pubescence of meso and metasoma entirely black (Fig. 5F). Hairs of outer fringe of foretarsus white with black tips (Fig. 3H-I). Under surface of foretarsus with dark brown 
spot on basitarsus and on second tarsomere. M. yana

-- Pubescence of meso and metasoma predominantly white (scutum and sometimes mesopleuron with intermixed black hairs, apical hair bands on T3-T5 yellowish, and disc of T5 with golden-brown hairs) (Fig. 5D). Hairs of outer fringe of foretarsus rufous (Fig. 3F-G). Under surface of foretarsus without spots. M. una

3.- Pubescence of venter of thorax, coxae, metasomal sterna, and T5 entirely black (Figs. 1D, 2E, 4B-C). ... 4

-- Pubescence of venter of thorax, coxae, and metasomal sterna white to yellowish. T5 with pale apical band (Figs. 4A, D-E). 5

4.- Pubescence very long, hairs on disc of scutum 2.3-3.0x MOD; hairs on disc of T2 white, dense, usually hiding apical band (Fig. 1D). Vertex narrow, distance from lateral ocellus to posterior margin of head 1.3x MOD.

M. fidalgoi

-- Pubescence moderate, hairs on disc of scutum 1.0-1.8x MOD; hairs on disc of T2 black, sparse, not hiding apical band (Fig. 2E). Vertex broad, distance from lateral ocellus to posterior margin of head 2.8-3.0x MOD.

M. joergenseni

5.- Apical fringes of S2-S3 with dense, long hairs (Fig. 2G); medially on S2 apical hairs 1.82.0x MOD. Foretarsus with second tarsomere brownish, concolorous with following tarsomeres (Fig. 3A). T3 with apical band entire. Appressed hairs on T6 white (Fig. 4A).

M. bruneriella

-- Apical fringes of S2-S3 with sparser, shorter hairs (Fig. 2F); medially on S2 apical hairs 0.8-1.6x MOD. Foretarsus with second tarsomere yellow, contrasting with brownish following tarsomeres (Fig. 3D-E). T3 with apical band medially broadly interrupted. Appressed hairs on $\mathrm{T} 6$ variable, usually yellow.

6.- Vestiture longer, hairs on scutum 1.8-3.0x MOD. Outer surface of mid and hind femora and tibiae, and discs of T3-T4, with white hairs. M. puntana

-- Vestiture shorter, hairs on scutum 1.3-1.6x MOD. Outer surface of mid and hind femora and tibiae, and discs of T3-T4, with black hairs.

\section{Megachile (Joergensenella) bruneriella Cockerell}

(Figs. 1A-B, 2G, 3A, 4A, 6Aa-Da, 10A)

Megachile bruneriella Cockerell, 1917: 239 (Holotype male, Argentina, Santa Fe, Carcarañá, L. Bruner, National Museum of Natural History, Washington D.C., examined through photographs)

Megachile (Chrysosarus) bruneriella: Raw, 2002: 9; 2007: 32. Moure et al., 2007: 955. Ascher \& Pickering, 2018.

Diagnosis. Females of this species can be distinguished from the females of other species which have pale apical bands on T2-T5, by the broad vertex and the vestiture of $\mathrm{T} 6$, which is entirely yellow. Males are distinguished from other males with a slender foretarsus and pale vestiture on the venter of the thorax and metasomal sterna, by the denser and longer hairs on the metasomal sterna, the dark, brownish second tarsomere of the foretarsus, and the broader vertex.

Male. Total length 9.5-11.5 mm; length of forewing 7.3-8.2 mm. Color. Black, except foretarsus reddish brown beyond apex of basitarsus, anterior tibial spur yellowish brown, under surface of anterior femur light brown on distal third, and mid and hind distotarsi reddish apically; second tarsomere of foretarsus with black, ellipsoid spot below. Wings infuscate, darker along costal margin of marginal cell, and on apex of forewing; veins and pterostigma dark brown; some specimens with yellowish brown prestigma and pterostigma. Pubescence. Yellowish on face; black on vertex and close to posterior orbit of eye; white on underside of head. Hairs black on center of scutum and scutellum, on lateral side of pronotum, on anterior and upper posterior angle of mesopleuron, on metapleuron and lateral and posterior sides of propodeum; other hairs of mesosoma white (some specimens with white hairs on entire mesopleuron and on posterior surface of propodeum). Legs with pale hairs, white to yellowish, including white outer fringe of foretarsus. Metasoma with white hairs on disc of T1, central part of disc of T2, and sterna, other hairs yellowish including apical bands; erect hairs on T5 golden yellow. Apical band on T1 restricted to extreme side, on T2 occupying lateral fourth to third of apical margin, on T3 entire or briefly interrupted medially, on T4-T5 entire. Hairs on disc of scutum long (1.1-1.9x MOD), longer on mesopleuron (1.8-2.5x MOD) and scutellum (1.8-2.3x MOD). Hairs of outer fringe of forebasitarsus 1.3-1.7x apical width of basitarsus, with 
some interspersed longer hairs up to 2.5x MOD. Outer fringe of mid basitarsus with long white hairs (basal ones up to $3.4 \mathrm{x}$ apical width of basitarsus). Hairs on disc of T2 2.0-2.7x MOD, on disc of T3 0.8-1.0x MOD. Apical hairs on S2 plumose, medially 1.8-2.0x MOD, longer than on S3 (1.3x MOD). Sculpture. Head with punctures on frons coalescent, on vertex separated by weakly tessellate interspaces $0.2-0.5 \mathrm{x} \mathrm{PD}$; punctures on center of disc of scutum separated by weakly tessellate interspaces $0.2-1.0 \mathrm{x} \mathrm{PD}$; punctures on mesopleuron below hypoepimeral area coalescent; on discs of T2-T3 separated by polished interspaces 0-2-0.5x PD. Morphology. Inner margin of eyes slightly convergent below, UID $1.15 \mathrm{x}$ LID. Vertex of head broad, distance between lateral ocellus and occipital margin of head 2.5-2.8x MOD. Lower margin of mandible with angle on distal third. Apical margin of clypeus with median emargination, without denticles. Maximum width of gena $0.8 \mathrm{x}$ maximum width of compound eye. Proportions of scape, pedicel and first three flagellomeres 3.0:0.8:1:1.2:1.3; first flagellomere $1.25 \mathrm{x}$ its apical width. Forecoxal spine present, strong, its length 1.0x MOD; basad to spine with group of stiff, decumbent, red setae hidden by long plumose hairs. Forebasitarsus cylindrical, length $3.3 \mathrm{x}$ its apical width. Preapical carina of T6 medially with small emargination and irregularly crenulate lateral to it. S5, S6, S8, and genital capsule, as in figures 6Aa-Da.

Female. Total length 11.3-13.0 mm; length of forewing 8.8-9.3 mm. Color. Black, except anterior tibial spur, distotarsi and claws reddish brown. Wings as in male. Pubescence. Head: white on paraocular areas, around antennal sockets and lower part of frons; some specimens with small white patch on gena behind middle of eye; other hairs black. White on scutum and scutellum encircling central black hairs, anteriorly on tegula, on metanotum, and dense tufts behind pronotal lobe and above propodeal spiraculum; other hairs of mesosoma including legs, black. Hairs on disc of scutum 1.1-1.3x MOD, longer on mesopleuron (1.3-1.8x MOD). Erect hairs on disc of T1-T2 white (on T2 1.0-1.4x MOD), on disc of T3-T4 yellowish (on T3 0.9-1.1x MOD), becoming golden yellow on T4-T6. Apical band on T1 white, restricted to lateral fourth of margin; apical bands on T2-T5 yellowish, complete; T6 entirely covered with yellowish hairs. Anterior surface of T1, S1, and base of S2 with black hairs. Scopa ferruginous from apex of S2 to apex of S6. Sculpture. Clypeus and supraclypeal area with dense punctures, separated by shiny interspaces 0.2-0.5x PD; some specimens with narrow, poorly defined median longitudinal impunctate stripe on upper half of clypeus. Acetabular interspace of mandible tessellate. Punctures on most of scutum dense, but on center of disc sparse, separated by tessellate interspaces $0.5-1.5 \mathrm{x}$ PD; punctures on mesopleuron below hypoepimeral area nearly coalescent. Discs of terga feebly tessellate; punctures on T3 rounded, separated by 0.2-0.5x PD, but on T4-T5 with posterior margins shallow, poorly defined, appearing as oblong punctures. Morphology. Inner margin of eyes slightly convergent below, UID 1.1x LID. Distance between lateral ocellus and occipital margin of head 2x MOD. Clypeus 2.4x as wide as long; apical margin with median denticle and 2-3 weakly defined denticles on each side of middle. Maximum width of gena 1.0x maximum width of compound eye. Proportions of scape, pedicel and first three flagellomeres 3.5:0.7:1:0.9:1.0; first flagellomere as long as $1.4 \mathrm{x}$ its apical width.

Comments. Digital images of the holotype are available in the online type catalog of the National Museum of Natural History, USA (National Museum of Natural History, Smithsonian Institution).

Distribution. Argentina, provinces of Buenos Aires, Chaco, Corrientes, and Santa Fe. Uruguay, departments of Montevideo and Cerro Largo.

Material studied. Argentina. Buenos Aires: 6 M, Buenos Aires, 4-IV-1904 and 11-IV-1904, J. Brèthes (MACN); 1 F, Buenos Aires, IV-1907, J. Brèthes (MACN); 1 M, Estancia Las Chilcas, partido de Pila, 5-II-2009, ex Vernonia rubricaulis, H. Marrero (FAUBA); 1 M, Estancia Las Chilcas, partido de Pila, 26-III-2009, ex Stemodia lanceolata, H. Marrero (MACN). Chaco: 2 F, Capitán Solari, P. N. Chaco $\left(26^{\circ} 53.474\right.$ S $\left.59^{\circ} 36.245 \mathrm{~W}\right), 5-\mathrm{V}-2008,26-\mathrm{V}-2008$, A. Taylor \& N. Veiga (MACN). Corrientes: $1 \mathrm{M}$, Santa Teresa, P. N. Mburucuyá $\left(28^{\circ} 01.233\right.$ S, $58^{\circ} 02.367$ W), 21-IX-2009, N. Veiga (MACN); 1 F, $2 \mathrm{M}$, Potrero Tung, P. N. Mburucuyá (2801.150 S, 5802.083 W), 21-IX-2009, 5-X-2009, 17-X-2009, N. Veiga (MACN). Uruguay. Montevideo: 1 F, Prado, 14-I-1925 (MLP). Cerro Largo: 4 F, Cuchilla de Melo, 15-XI-1916 (MACN). 


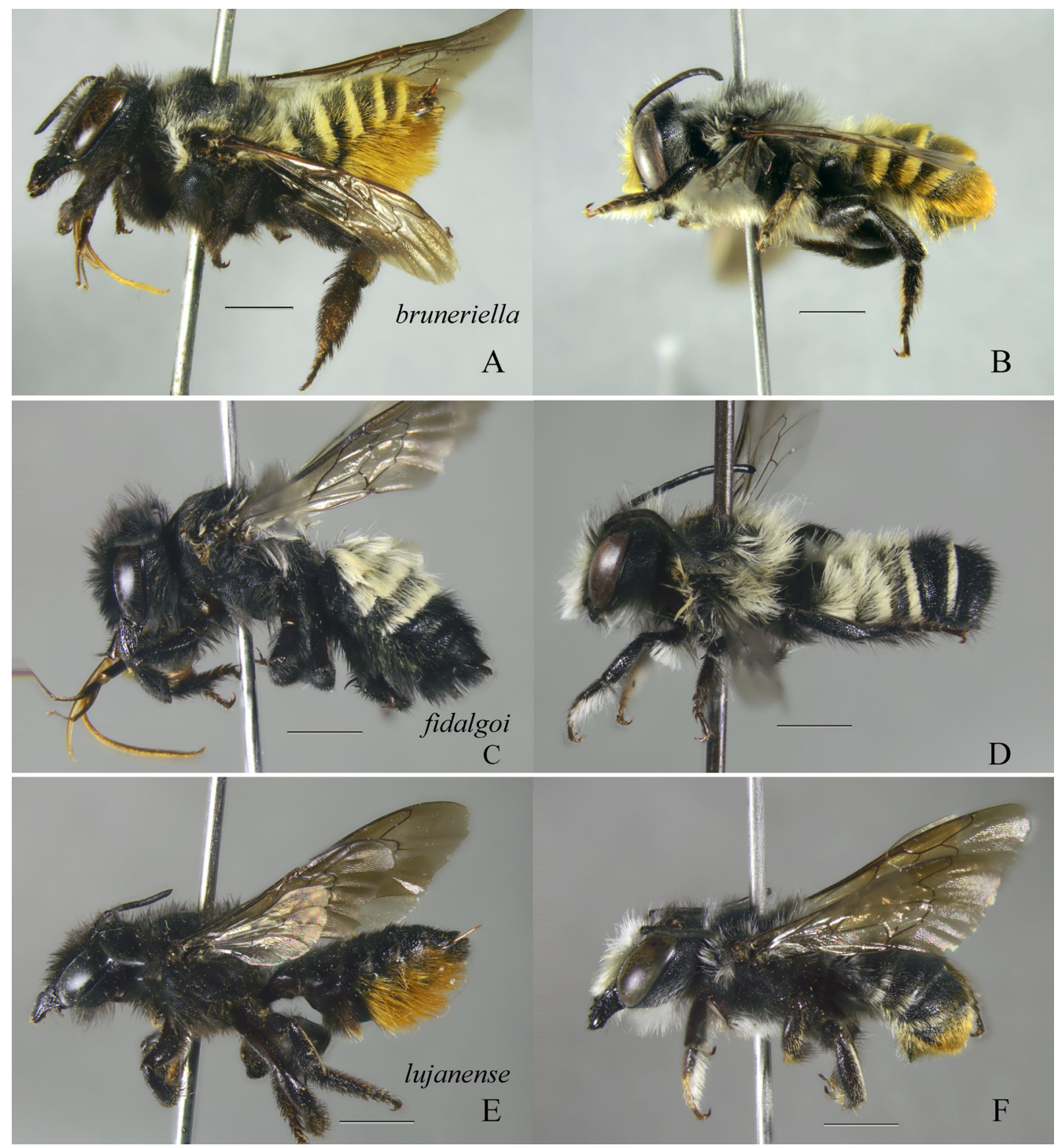

Fig. 1.Megachile (Joergensenella) species, lateralview. A,M.bruneriella female. B, M. bruneriella male.C,M.fidalgoi, female. D, $M$. fidalgoi, male holotype. E, M. lujanense, female. F, M. lujanense, male holotype. Scale lines $=2 \mathrm{~mm}$.

Megachile (Joergensenella) fidalgoi n. sp.

(Figs. 1C-D, 3B, 4B, 6Ab-Db, 10A)

urn:lsid:zoobank.org:act:AC982B6E-91F8-48049AC4-AAB32D529028

Diagnosis. This species is distinguished by the narrow vertex (1.2x MOD in the female and 1.3x MOD in the male), and the color pattern of the vestiture of the metasoma, the first three terga being entirely covered by dense, long, white hairs in both sexes, while the vestiture of the apical terga is entirely black in the female, and black with an apical white band on T4 in the male (Fig. 1C-D). The genital capsule and S5-S6 of the male suggest a close relationship to $M$. joergenseni.

Male holotype. Total length $10.5 \mathrm{~mm}$; length of forewing $7.7 \mathrm{~mm}$. Color. Black, except part of tarsi as follows: anterior basitarsus on apical third of under surface yellowish brown, following tar- 
someres all yellowish brown, but second with ellipsoid black spot on under side; distotarsi of mid and hind legs reddish brown. Wings weakly infuscated, darker along costal margin of marginal cell, and apex of forewing; veins and pterostigma dark brown. Pubescence. Head: white on clypeus, supraclypeal area, around antennal insertions, and hypostomal area; black on remainder of head. Mesosoma: Hairs white on pronotum, on scutum and scutellum surrounding black central hairs, on metanotum, propodeum, upper part of pleurae, outer surface of forefemur, outer fringe of foretarsus (with some interspersed black hairs), and on apex of mid femur; other hairs black. Hairs on disc of scutum long (2.3-3.0x MOD), longer on mesopleuron (3.0-3.6x MOD) and scutellum (2.3-3.6x MOD). Outer fringe of forebasitarsus with hairs (white) 1.3-1.8x apical width of basitarsus, with some interspersed longer hairs (black) up to 3.1x MOD. Mid and hind legs with black hairs, except tarsi with yellowish brown hairs, and outer fringe of mid basitarsus with long white hairs (basal ones up to 3.7x apical width of basitarsus). Metasoma: white hairs on discs of T1-T2 long and dense, hiding integument (1.3-2.7x MOD), on disc of T3 sparse and intermixed with some black hairs; T1-T4 with apical bands of short, dense white hairs (0.7-0.9x MOD); remainder of metasoma with black hairs. S2-S4 with apical hairs 1.1-1.3x MOD medially. Sculpture. Head with punctures on frons and vertex separated by shiny interspaces $0.2-0.5 \mathrm{x}$ PD; punctures on disc of scutum and mesopleuron dense, separated by shiny interspaces $0.2-0.3 \mathrm{x}$ PD; punctures on discs of T2-T3 deep, irregular in size, separated by shiny interspaces $0.2-1.0 \mathrm{x}$ PD. Morphology. Inner margin of eyes slightly convergent below, UID 1.15x LID. Vertex of head narrow, distance between lateral ocellus and occipital margin of head 1.3x MOD. Lower margin of mandible with angle on distal third. Apical margin of clypeus with median emargination, without distinct denticles. Maximum width of gena $0.85 \mathrm{x}$ maximum width of compound eye. Proportions of scape, pedicel and first three flagellomeres 2.8:0.8:1:1.4:1.4; first flagellomere $1.25 \mathrm{x}$ its apical width. Forecoxal spine present, strong, its length 1.0x MOD; basad to spine with group of stiff, decumbent, black setae hidden by long plumose hairs. Forebasitarsus cylindrical, 3.1x its apical width. Preapical carina of T6 medially emarginate. S5, S6, S8, and genital capsule, as in figures $6 \mathrm{Ab}-\mathrm{Db}$.

Female. Total length $10.7 \mathrm{~mm}$; length of forewing $8.5 \mathrm{~mm}$. Color. Entirely black, except claws dark reddish brown. Wings as in male. Pubescence. Black on head and legs. Mesosoma with white hairs on posterior margin of pronotum, on scutum and scutellum surrounding central black hairs, tuft behind pronotal lobe, tuft on anterior part of tegula, on metanotum and upper part of propodeum; remainder of mesosoma with black hairs. Hairs very long on disc of scutum (1.6-3.2x MOD) and mesopleuron (2.1-3.0x MOD). T1-T3 entirely covered with long white hairs (on T2 1.7-2.3x MOD, on T3 1.3-2.0x MOD), and without discernible apical bands; T4 laterally with apical band of intermixed black and white hairs; remainder of metasoma with black hairs, including scopa. Sculpture. Clypeus and supraclypeal area with dense punctures, separated by shiny interspaces 0.1-0.5x PD, and with median longitudinal, impunctate stripe reaching to mid apical denticle of margin of clypeus. Acetabular interspace of mandible polished. Punctures on disc of scutum dense, separated by shiny interspaces 0.2-0.5x PD; punctures on mesopleuron below hypoepimeral area nearly coalescent. Discs of terga shiny; punctures on T3-T5 with posterior margins shallow, poorly defined, appearing as oblong punctures. Morphology. Inner margin of eyes slightly convergent below, UID 1.1x LID. Vertex of head narrow, distance between lateral ocellus and occipital margin of head 1.2x MOD. Clypeus 2.3x as wide as long; apical margin of clypeus with median denticle and 2-3 denticles on each side of middle. Maximum width of gena 1.0x maximum width of compound eye. Proportions of scape, pedicel and first three flagellomeres 3.3:0.7:1:0.7:0.8; first flagellomere as long as $1.4 \mathrm{x}$ its apical width.

Etymology. The species name is after the Argentinean hymenopterist Patricio Fidalgo, who collected the holotype.

Distribution. Argentina, province of Jujuy.

Material studied. Holotype male, Argentina, Jujuy, Puerta de Lipán, Ruta 52 km 18, 10-11-X2009, 2900 m, YPT, P. Fidalgo (MACN). Paratypes: $1 \mathrm{~F}$, same data as holotype (MACN); $1 \mathrm{~F}$, Jujuy, 8 km E El Quemado, 3544 m (-23.67734 -65.60934), 14-IV-2018, R. González Vaquero (MACN).

Megachile (Joergensenella) joergenseni Friese (Figs. 2A-E, 3C, 4C, 4H, 6Ac-Dc, 7A, 10B)

Megachile jörgenseni Friese, 1908: 63, 66 (Lectotype female, Mendoza, Argentina, 20-11-1906, Museum 


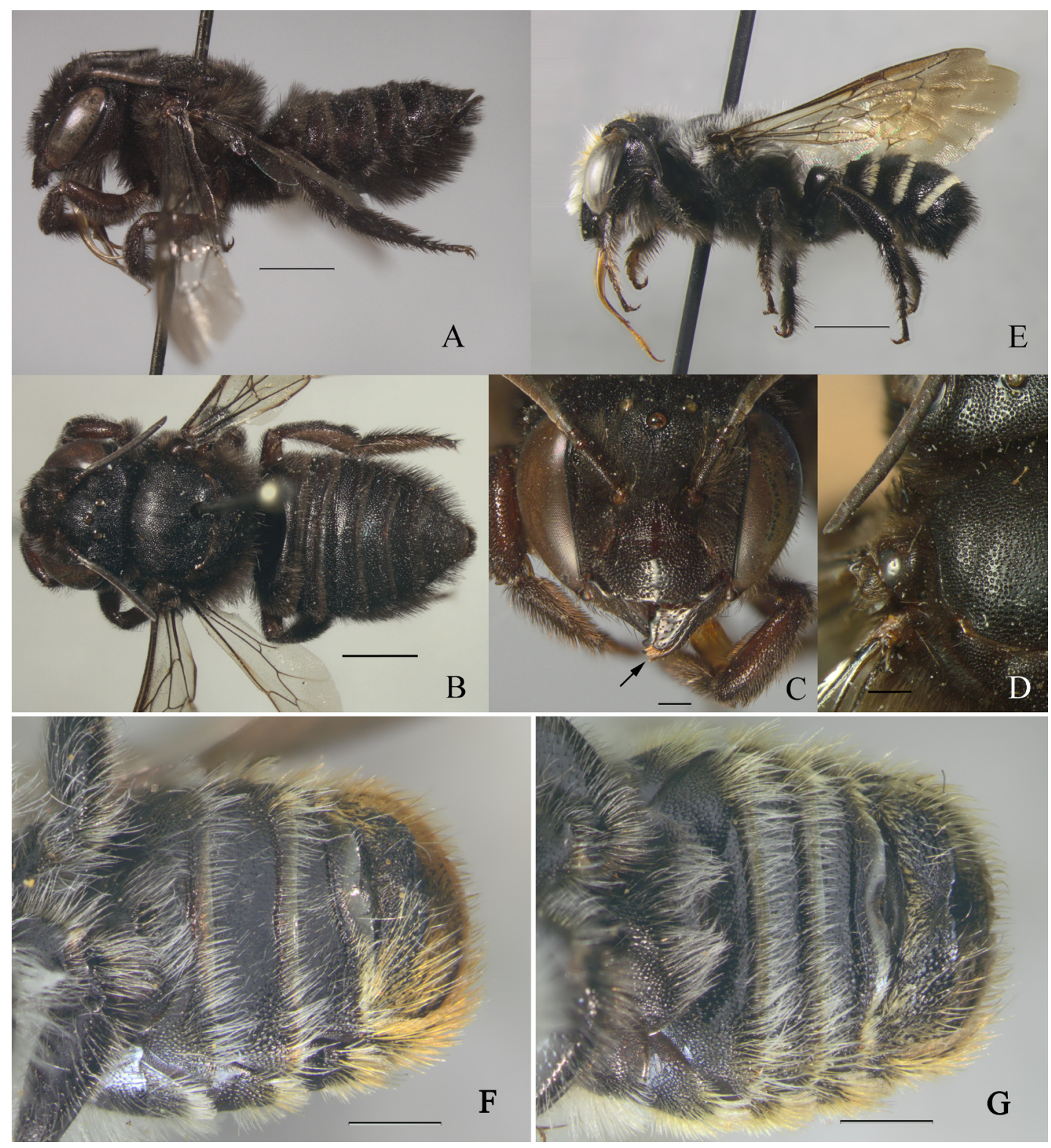

Fig. 2. A-E, M. (Joergensenella) joergenseni. A-D, female lectotype: A, lateral view; B, dorsal view; C, face (arrow: apical brushes of mandible); D, detail of punctation on head and scutum. E, male, lateral view. F-G, male metasomal sterna. F, M. puntana. G, M. bruneriella. Scale lines: A, B, and E = $2 \mathrm{~mm}$; C-D = $0.5 \mathrm{~mm} ; \mathrm{F}-\mathrm{G}=1 \mathrm{~mm}$.

für Naturkunde, Berlin, examined, present designation). Jensen Haarup, 1908a: 105; 1908b: 110. Jörgensen, 1909: 214; 1912a: 126, 132; 1912b: 310. Schrottky, 1913: 247, 251.

Megachile joergenseni: Toro \& Fritz, 1991: 70. Moure et al. 2007: 999.

Megachile burmeisteri Friese, 1908: 63, 64, 68 (Lectotype male, Mendoza, Argentina, 20-XII1906, Museum für Naturkunde, Berlin, examined through photographs, present designation). Jensen-Haarup, 1908a: 106; 1908b: 110. Vachal,
1909: 7. Jörgensen, 1909: 215; 1912a: 130, 134; 1912b: 311. Schrottky, 1913: 247. Schrottky, 1920: 206, 207. New synonym.

Megachile atramentata Cockerell, 1917: 238 (Holotype female, Argentina, Bahía Blanca, United States National Museum, Washington D.C., examined through photographs). Mitchell, 1930: 173, 256 (as atromentata). Synonymy indicated by Moure et al. 2007: 999.

Megachile (Cressoniella) atramentata: Raw, 2002: 13; 2007: 41. 
Megachile (Dasymegachile) joergenseni: Durante and Abrahamovich, 2006: 795, 796, 797. Raw, 2007: 45. Ascher \& Pickering, 2018.

Diagnosis. The female is recognized by its entirely black vestiture. It can only be confused with $M$. yana, from which it is readily distinguished by the median impunctate longitudinal stripe of the clypeus (Fig. 2C), and the anterior tibial spur with the apex concolorous with the remainder of the spur (Fig. $4 \mathrm{H}$ ). The male most resembles $M$. fidalgoi, due to the black vestiture of the metasomal sterna, the complete white apical bands on T1-T4, and the group of stiff setae close to the forecoxal spine being black and not reddish as in the other species of Joergensenella (and as in most Megachile, when they are present). It can be distinguished from fidalgoi by the shorter vestiture, the black hairs on the disc of T3, and the broad vertex.

Male. Total length 8.8-12.0 mm; length of forewing $6.8-8.8 \mathrm{~mm}$. Color. Integument black, except anterior tarsus with second tarsomere yellowish to reddish brown (with black, ellipsoid spot below), anterior tibial spur yellowish brown, and under surface of anterior femur light brown on distal two thirds. In some specimens, anterior tarsus reddish brown beyond apex of basitarsus. Wings hyaline, infuscate along costal margin of marginal cell, and on apex of forewing; veins and pterostigma dark brown. Pubescence. White on most of head, except intermixed black and white hairs on vertex; black on mandible, close to posterior orbit of eye, and on hypostomal area close to proboscideal fossa. White on pronotum dorsally, on tegula anteriorly, on scutum and scutellum encircling black hairs, on metanotum, dense tufts behind pronotal lobe and above propodeal spiraculum; variable on mesopleuron, white hairs restricted to patch behind and below pronotal lobe to lateral part of mesopleuron all covered with white hairs; outer surface of forefemur with white hairs (in some specimens extending to trochanter); outer fringe of foretarsus with white hairs on apex of basitarsus and on second and third tarsomeres (some specimens with few white hairs intermixed with black ones); remainder of mesosoma and legs with black hairs. Hairs on disc of scutum 1.0-1.8x MOD, longer on mesopleuron (2.0-2.5x MOD) and scutellum (2.0-3.0x MOD). Hairs of outer fringe of forebasitarsus 1.4-1.6x apical width of basitarsus, with some interspersed longer hairs up to 2.0x MOD. Outer fringe of mid basitarsus with long hairs (basal ones up to 2.6x apical width of basitarsus). Metasoma with white hairs on disc of $\mathrm{T} 1$, central part of disc of T2 (1.5-2.5x MOD), and dense apical bands on T1-T4; in some specimens apical bands on T3-T4 yellowish; other hairs black; hairs on disc of T3 short (1.0-1.2x MOD); hairs on apex of T5 stiff and simple, not forming band. S2-S4 with sparse apical hairs (on S2 1.5-1.8x MOD medially). Sculpture. Head with punctures on frons and vertex separated by shiny interspaces $0.2-0.5 \mathrm{x}$ PD; punctures on center of disc of scutum separated by weakly tessellate interspaces 0.2-1.0x PD; punctures on mesopleuron below hypoepimeral area coalescent; on discs of T2-T3 separated by polished interspaces $0.2-1.0 \mathrm{x}$ PD. Morphology. Inner margin of eyes slightly convergent below, UID 1.15x LID. Vertex of head broad, distance between lateral ocellus and occipital margin of head 2.8-3.0x MOD. Lower margin of mandible with angle on distal third. Apical margin of clypeus with median emargination, without denticles. Maximum width of gena $1 x$ maximum width of compound eye. Proportions of scape, pedicel and first three flagellomeres 3.1:0.9:1:1.4:1.6 first flagellomere $1.12 \mathrm{x}$ its apical width. Forecoxal spine present, strong, its length 1.3x MOD; basad to spine with group of stiff, decumbent, black setae hidden by long plumose hairs. Anterior basitarsus cylindrical, 3.4x its apical width. Preapical carina of T6 medially emarginate. S5, S6, S8 and genital capsule, as in figures $6 \mathrm{Ac}-\mathrm{Dc}$.

Female lectotype. Total length $11.7 \mathrm{~mm}$ (other specimens 10.3-13.2 mm); length of forewing $9.2 \mathrm{~mm}$ (other specimens 7.9-9.3 $\mathrm{mm}$ ). Color. Entirely black, except claws dark reddish brown. Wings as in male. Pubescence. Black, except apical mandibular brushes ferruginous. Scopa black. Hairs on disc of scutum 0.6-1.0x MOD, on mesopleuron 1.0-1.3x MOD. T2-T5 with complete apical bands of black, plumose hairs; discs of T1-T5 with erect hairs (1.0-1.5x MOD on T2, 0.5-0.8x MOD on T3); T6 with decumbent, plumose hairs and interspersed erect, simple hairs. Sculpture. Clypeus and supraclypeal area with dense punctures, separated by shiny interspaces 0.1-0.5x PD, and with median, longitudinal, impunctate stripe reaching to mid apical denticle of margin of clypeus. Acetabular interspace of mandible polished. Punctures on most of scutum dense, but on center of disc sparse, separated by tessellate interspaces 0.5-1.0x PD; punctures on mesopleuron below hypoepimeral area nearly coalescent. Discs of terga polished; punctures 


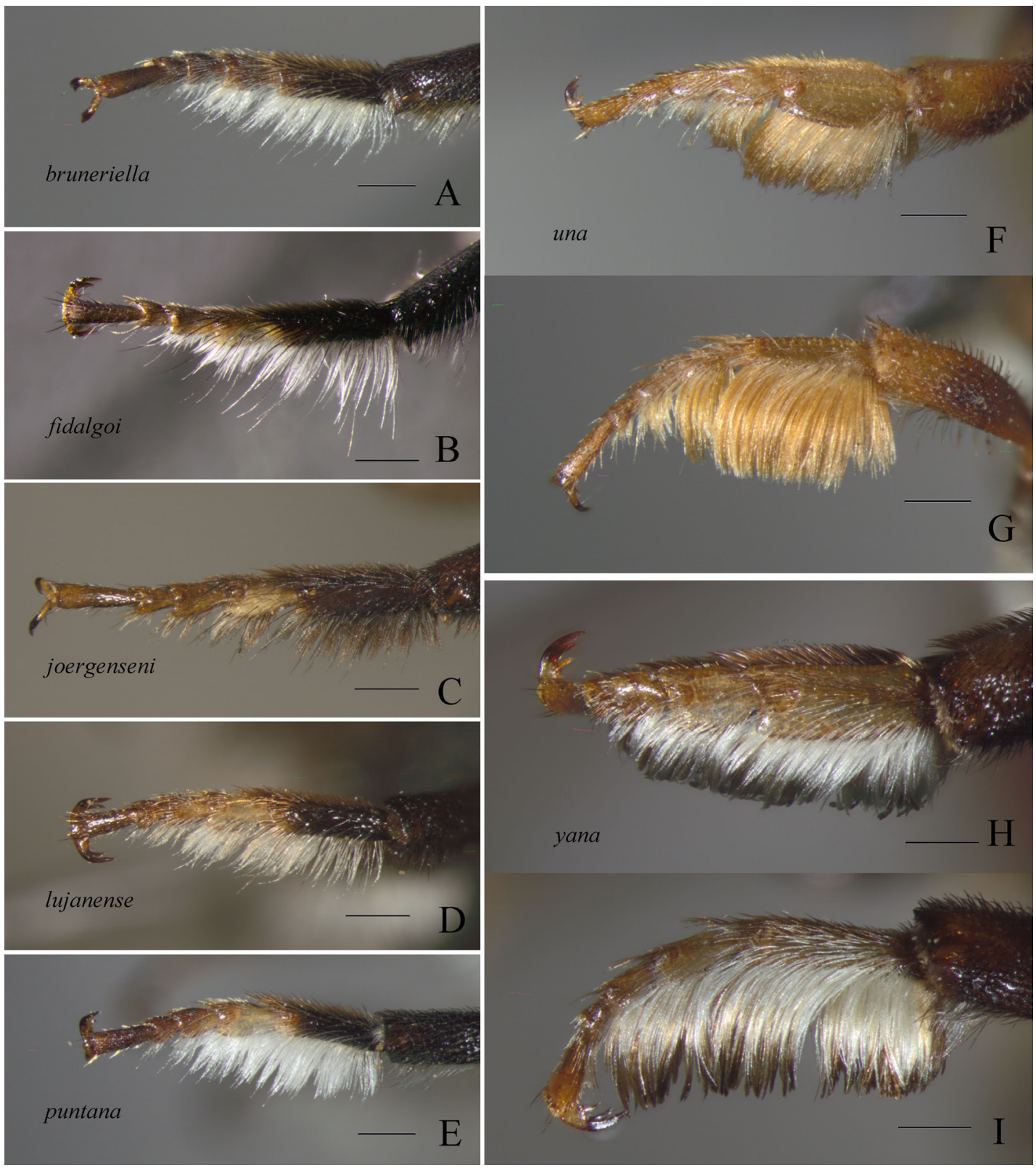

Fig. 3. Megachile (Joergensenella) species, anterior tarsus of males, dorsal views, except G and I, lateral views. A, M. bruneriella. B, M. fidalgoi. C, M. joergenseni. D, M. lujanense. E, M. puntana. F-G, M. una. H-I, M. yana. Scale lines $=0.5 \mathrm{~mm}$.

on T3-T4 rounded, separated by $0.5-1.5 \mathrm{x}$ PD. Morphology. Inner margin of eyes slightly convergent below, UID 1.13x LID. Distance between lateral ocellus and occipital margin of head $2 x$ MOD. Clypeus 2.24x as wide as long; apical margin with median denticle and crenulate to weakly denticulate on each side of middle. Maximum width of gena $1.0 \mathrm{x}$ maximum width of compound eye. Proportions of scape, pedicel and first three flagellomeres 3.3:0.8:1:0.9:0.9; first flagellomere as long as $1.2 \mathrm{x}$ its apical width.

Comments. A female specimen in the Museum für Naturkunde (Berlin) collection is selected as the lectotype of $M$. joergenseni Friese. It bears the following labels: "Argentina / Mendoza / 
20-11-1906," "Megachile / jörgenseni / 1907 Friese det. / [female symbol] Fr.," "Type," "Zool. Mus. / Berlin," and "Megachile / joergenseni / LECTOTYPUS / Friese 1908 / det. S. Durante." Friese (1908), in his description of M. burmeisteri, misassociated males with females of a different species. A male from the composite type series of Megachile burmeisteri preserved in Berlin is selected as the lectotype. It bears the following labels: "Argentina Mendoza / 20-XII-1906," "Meg. burmeisteri / 1907 Friese det," "Type," and "Zool. Mus. Berlin." This male described as M. burmeisteri corresponds to the male of $M$. joergenseni. Male specimens identified as $M$. burmeisteri by Jensen Haarup (1908a, 1908b), Vachal (1909) and Jörgensen (1909, 1912a, 1912b) agree with this interpretation. On the other hand, the citations of $M$. burmeisteri based on female specimens (Cockerell, 1919; Mitchell, 1930) led to the interpretation of the species as belonging to the subgenus Pseudocentron (Mitchell, 1943; Raw, 2007; Moure et al. 2007). These citations are not included in the synonymy of $M$. joergenseni above.

Distribution: Argentina, provinces of Buenos Aires, Catamarca, Chubut, Córdoba, La Pampa, La Rioja, Mendoza, Neuquén, Río Negro, Santa $\mathrm{Fe}$, and Santiago del Estero.

Material studied. (All female specimens in MLP cited by Durante and Abrahamovich (2006: 797) were examined; their data are not repeated here, but are included in the distribution map). Argentina. Buenos Aires: $1 \mathrm{M}$, Bahía Blanca (MACN); 2 F, Patagones, 12-I- 1937, M. J. Viana (MACN); 1 M, 1 F, Felipe Solá, Depto. Puan, XII1951 and II-1951, A. Martínez (SEMC); 1 M, Sierra de la Ventana, I-1953, F. Walz (SEMC). Catamarca: San Fernando, $50 \mathrm{~km}$ N Belén, 4-XI-1989, ex Wedelia sp., L. Moffatt (MACN). Chubut: 2 F, San Jorge \# 7417 (MACN). Córdoba: 1 F, El Sauce, Dpto. Calamuchita, XII1938, J. Viana (MACN); 1 F, Agua de Oro, I-1940, De Carlo (SEMC). La Pampa: 2 F, Conhelo, I-1942, Hepper (MACN); 1 F, 15-I-1972 (MACN); $1 \mathrm{~F}$, La Graña, 6-V-2008, O. Di Iorio (MACN); 3 M, \# 6648 (MACN); 1 F, Lihue Calel, 13-II-2007, L. Compagnucci (MACN); 4 M, Toay, Estancia Anquiloo, H. Marrero col, 2 M, 17-I-2009 ex Chuquiragaerinacea, 1 M, 18-I-2009 ex Centaurea solsticialis, 1 M, 16-I-2009 ex Cirsium vulgare (MACN). La Rioja: 1 F, Sierra de las Minas, 22I-1922 (MACN); 1 F, Iliar, M. Gómez (MACN); 4 F, Departamento Belgrano, III-1929, M. Gómez (MACN); 3 F, 1 M, La Rioja, Giacomelli (MACN);
$1 \mathrm{~F}$, camino a Laguna Brava, 2366 m, 28-I-2006, L. Compagnucci (MACN). Mendoza: 1 F, 6 M, Cacheuta (MACN); 1 F, 1 M, Ñacuñán, I-1976, A. Roig A. (IADIZA); $1 \mathrm{M}$, Tupungato, Valle de La Carrera, 26-I-1995, A. Roig A. (MACN); 1 M, Carrizal del Medio, 23-II-1997, A. Roig A. (MACN); 2 F, Álvarez Condarco, 25-II-1997, on flowers of Psilla retamoides, A. Roig A. (MACN); $20 \mathrm{M}$, Villavicencio, 24-X/21-XI-2008, 21-X/5-XI2009, 4-X/29-XI-2011, D. Vázquez, N. Chacoff \& J. Dorado (IADIZA, MACN); 2 M, Mendoza, 2530-V-1908, P. Jörgensen (MLP); 1 M, Mendoza, 20-IX-1941, A. Ogloblin (MLP); 1 M, Uspallata, 16-XII-1954, A. Ogloblin (MLP). Neuquén: 1 M, Río Agrio, 21-I-1921, Kraglievich (MACN); 1 F, Zapala, III-1955, J. Foerster (SEMC). Río Negro: 1 F, old INTA station, c. $13 \mathrm{~km}$ W Gral. Roca, 25-II-1998, C. \& M. Vardy (NHMUK); 1 F, Gral. Roca, A. Garciso (MACN); 1 M, Conesa, XI1950 (SEMC); 1 M, Río Colorado, 16-II-1913, P. Jörgensen (MLP); 1 M, Río Colorado, III-1958, A. Ogloblin (MLP). Santa Fe: 1 F, Rosario (MACN). Santiago del Estero: 2 F, Depto. Matará, Desvío 511, 24-X-1928 (SEMC).

Megachile (Joergensenella) lujanense n. sp. (Figs. 1E-F, 3D, 4D, 6Ad-Dd, 7B, 10A)

urn:lsid:zoobank.org:act:CDC7CBBD-2FEB4524-81FE-415DE30CF641

Diagnosis. This species is distinguished in the female sex by the orange scopa contrasting with the black vestiture of the mesosoma and metasomal terga. The male is distinguished, among males with slender forebasitarsus and white vestiture on the metasomal sterna, by the broadly interrupted apical bands on T2-T3 and the black vestiture on the outer surface of the mid and hind femora and tibiae, and on the discs of T3-T4.

Male holotype. Total length $9.3 \mathrm{~mm}$ (paratypes 7.8-9.8 mm); length of forewing $7.5 \mathrm{~mm}$ (paratypes 6.5-7.8 mm). Color. Integument black, except anterior tarsus with second tarsomere yellowish (with black, ellipsoid spot below), and apex of basitarsus and tarsomeres third to fifth yellowish brown; anterior tibial spur yellowish brown; mid and posterior tibial spurs dark reddish brown; under surface of anterior femur light brown on distal two thirds. Tegula black; wings weakly infuscate, darker along basal vein, costal margin of marginal cell, and apex of forewing; veins and pterostigma dark brown. Pubescence. Head: white on clypeus, paraocular area, antennal scape, lower part of 


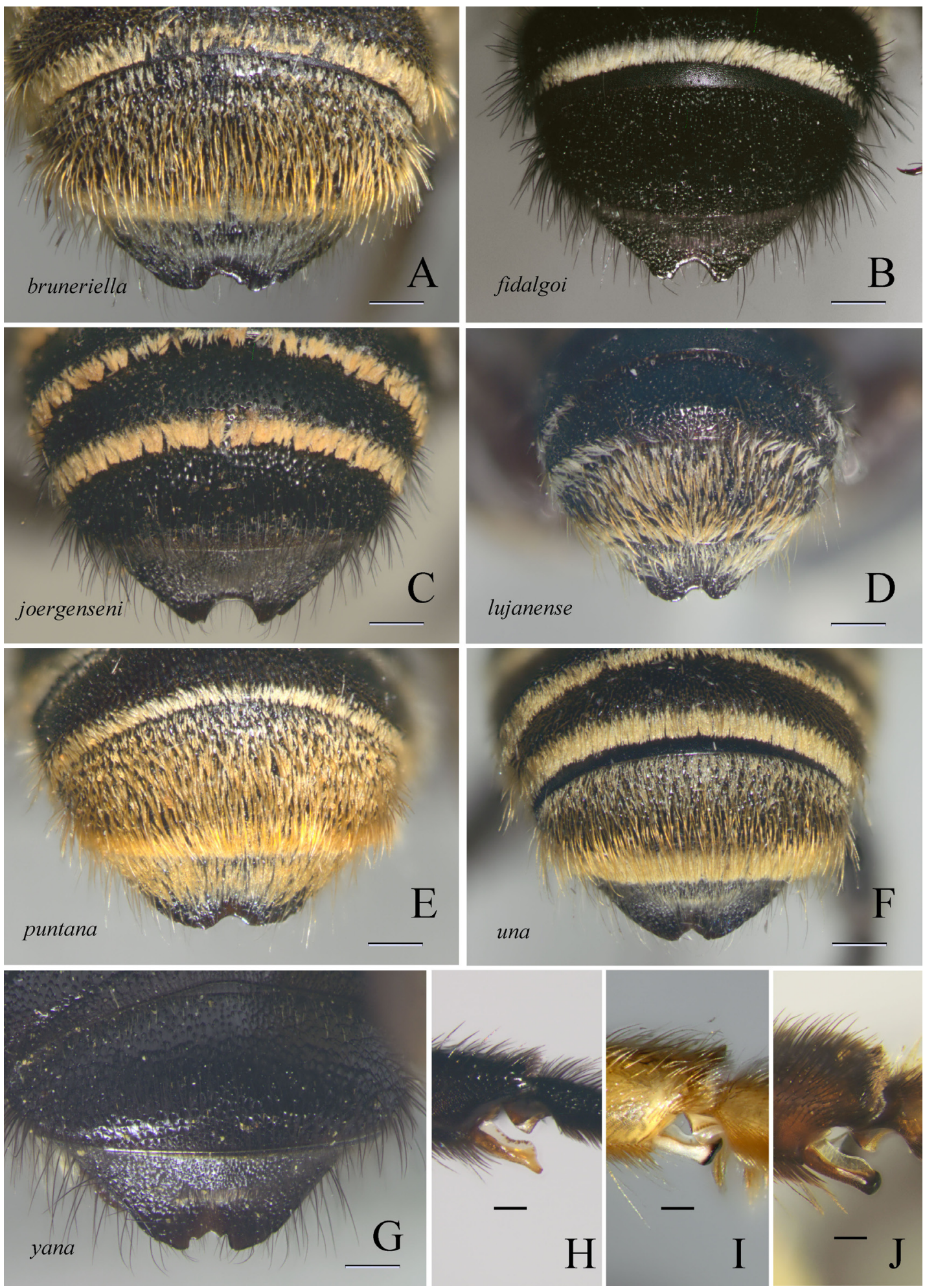

Fig. 4. Megachile (Joergensenella) species. A-G, T4-T6 of male, dorsal views. A, M. bruneriella. B, M. fidalgoi. C, M. joergenseni. D, M. lujanense. E, M. puntana. F, M. una. G, M. yana. H-J, anterior tibial spurs of females. H, M. joergenseni. I, M. una. J, M. yana. Scale lines, A-G $=0.5 \mathrm{~mm}$; H-J $=0.2 \mathrm{~mm}$. 
gena, and hypostomal area; black on remainder of head. Mesosoma: black, except white tuft behind pronotal lobe, white hairs on lower part of mesopleuron, and intermixed white and black hairs on anterior and lateral margins of scutum and sides of scutellum. Hairs on disc of scutum long (1.3-1.6x MOD), longer on mesopleuron (1.3-1.8x MOD) and scutellum (1.3-2.3x MOD). Foreleg with long white hairs on apex of coxa, under surface of trochanter, outer side of femur and outer fringe of tarsus; hairs on inner surface of tarsus yellowish brown; remainder of leg with black hairs. Hairs of outer fringe of forebasitarsus 1.4-1.6x apical width of basitarsus, with some interspersed longer hairs up to 2.3x MOD. Mid and hind legs with black hairs, except tarsi with yellowish brown hairs, and outer fringe of mid basitarsus with long white hairs (basal ones up to $3.0 \mathrm{x}$ apical width of basitarsus). Metasoma: $\mathrm{T} 1$ with hairs black and some interspersed white hairs laterally (entirely black in one paratype); without apical band. T2-T4 with black hairs on disc (1.1-1.4x MOD on T2, 0.8-1.0x MOD on T3); apical bands of plumose white hairs broadly interrupted on T2-T3, briefly so on T4 (apical band complete on T4 in one paratype). T5-T6 on disc with short, plumose, decumbent yellowish hairs (0.3-0.6x MOD on T5) and intermixed long, simple, golden brown hairs (1.1-1.4x MOD on T5); T5 with complete apical band of yellowish plumose hairs. S2-S4 with sparse pale apical hairs (0.8-1.1x MOD medially on S2). Sculpture. Head with punctures on frons nearly coalescent, on vertex separated by shiny interspaces $0.2-0$ .5x PD; punctures on disc of scutum separated by weakly tessellate interspaces $0.2-0.8 \mathrm{x} \mathrm{PD}$; punctures on mesopleuron below hypoepimeral area coalescent; on discs of T2-T3 separated by shiny interspaces $0.5-1.5 x$ PD. Morphology. Inner margin of eyes slightly convergent below, UID 1.1x LID. Distance between lateral ocellus and occipital margin of head 1.8x MOD. Lower margin of mandible with angle on distal third. Apical margin of clypeus with median emargination, without distinct denticles. Maximum width of gena $0.8 \mathrm{x}$ maximum width of compound eye. Proportions of scape, pedicel and first three flagellomeres 3.1:0.8:1:1.3:1.4; first flagellomere $1.12 \mathrm{x}$ its apical width. Forecoxal spine present, strong, its length 1.2x MOD; basad to spine with group of stiff, decumbent, reddish setae hidden by long plumose hairs. Anterior basitarsus cylindrical, 3.2x its apical width. Preapical carina of T6 medially emarginate. S5, S6, S8, and genital capsule, as in figures $6 \mathrm{Ad}-\mathrm{Dd}$.
Female. Total length 9.6-11.3 mm; length of forewing 7.3-8.8 mm. Color. Integument black, including mandible and antenna; anterior tibial spur yellowish brown with apex darkened distally; mid and posterior tibial spurs dark reddish brown. Wings as in male. Pubescence. Black, except a few white hairs on base of scape, brown hairs on inner side of tarsi, orange hair tufts on apex of mandible, and orange scopa on S3-S4; S2 with orange hairs apically to entirely black; S6 with orange hairs basally to entirely orange. Hairs on disc of scutum long, 1.4-2.1x MOD, longer on mesopleuron (2.1-3.0x MOD). T2-T4 with apical lateral bands of black, plumose hairs; apical hairs on T5 and on T2-T4 medially stiff and simple; discs of T1-T5 with long, erect hairs (1.6-2.1x MOD on T2, 1.0-1.6x MOD on T3); T6 with decumbent, plumose hairs and interspersed erect, simple hairs. Sculpture. Clypeus and supraclypeal area with dense punctures, separated by shiny interspaces $0.10-0.25 \mathrm{xD}$, and with median longitudinal, irregular, impunctate stripe not reaching apical margin of clypeus. Acetabular interspace of mandible finely tessellate. Punctures on disc of scutum irregularly distributed, separated by weakly tessellate interspaces $0.5-1.2 \mathrm{x}$ PD; punctures on mesopleuron below hypoepimeral area separated by tessellate interspaces $0.2-0$ $.5 x$ PD. Discs of terga shiny; punctures on T3-T5 with posterior margins shallow, poorly defined, appearing as oblong punctures. Morphology. Inner margin of eyes slightly convergent below, UID 1.1x LID. Vertex of head narrow, distance between lateral ocellus and occipital margin of head 1.6x MOD. Clypeus 2.2x as wide as long; apical margin of clypeus with median denticle and weakly denticulate on each side of middle. Maximum width of gena $0.8 \mathrm{x}$ maximum width of compound eye. Proportions of scape, pedicel and first three flagellomeres 3.5:0.8:1:0.9:1.0; first flagellomere as long as $1.2 \mathrm{x}$ its apical width.

Etymology. The species name is taken from the type locality, department of Luján in the province of Mendoza.

Distribution. Argentina, province of Mendoza.

Material studied. Holotype male, Argentina, Mendoza, Departamento Luján, El Salto, 21-XII1995, A. Roig A. (MACN). Paratypes: Argentina, Mendoza: $1 \mathrm{~F}$, same data as holotype (MACN); $1 \mathrm{~F}$, Cacheuta (MACN); 1 F, 2 M, Departamento Luján, 16 km W Potrerillos, XII-1996, G. Roitman \& D. Medán (MACN). 

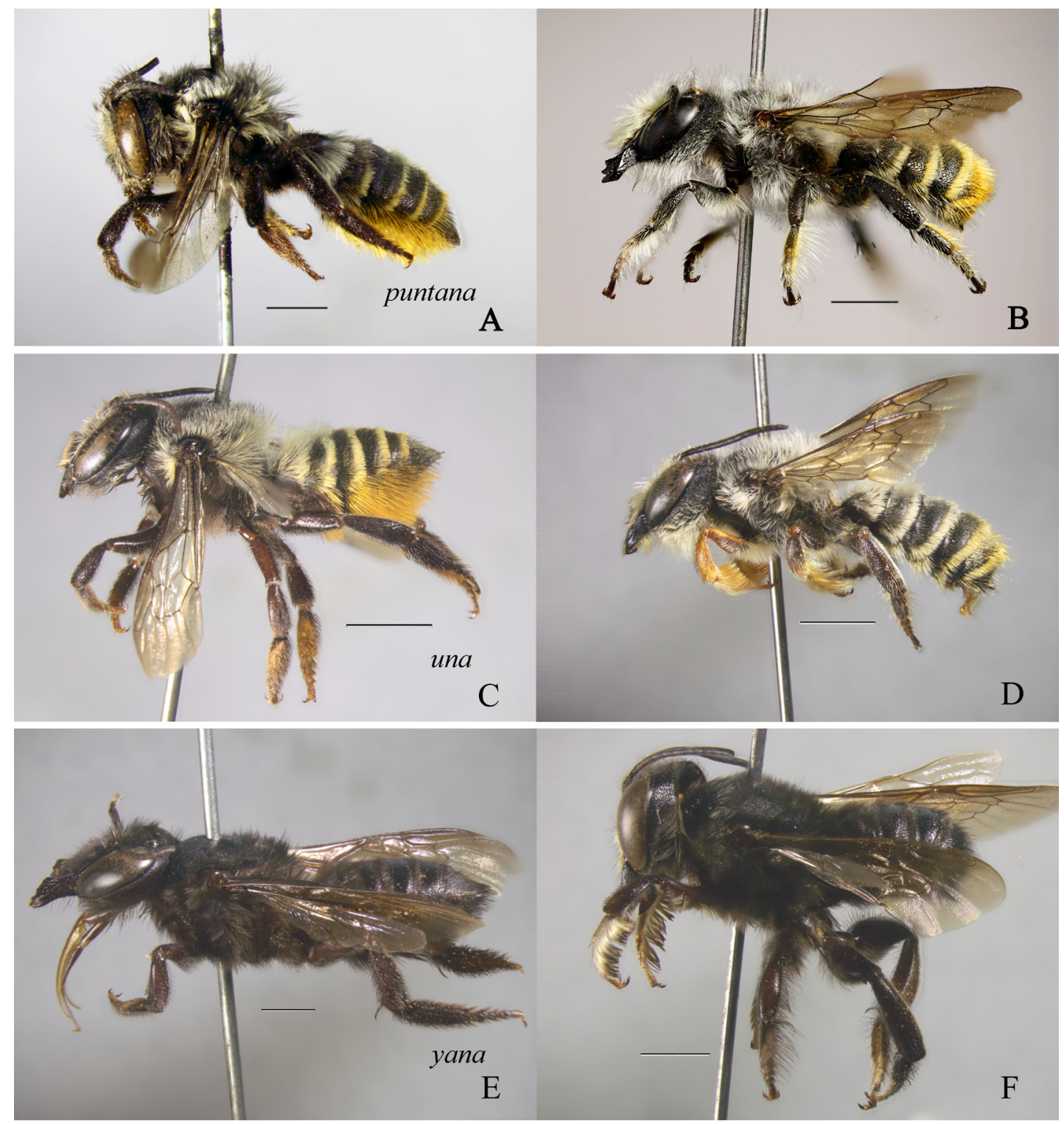

Fig. 5. Megachile (Joergensenella) species, lateral view. A, M. puntana, female. B, M. puntana, male holotype. C, M. una, female. D, M. una, male. E, M. yana, female. F, $M$. yana, male holotype. Scale lines $=2 \mathrm{~mm}$.

Megachile (Joergensenella) puntana n. sp. (Figs. 2F, 3E, 4E, 5A-B, 8Aa-Da, 10C)

urn:lsid:zoobank.org:act:C1B2CB7C-6195-40A4BF5C-0D2BE5C8BB55

Diagnosis. The female of this species shares with $M$. una and $M$. bruneriella the presence of pale metasomal apical bands on T2-T5. It is readily distinguished from $M$. una by the unmodified hairs of the face, and from M. bruneriella by the narrow vertex and the dark vestiture of
T6. Males are most similar to males of lujanense, from which they are distinguished by the longer vestiture and the white vestiture on the legs and on the metasomal terga.

Male holotype. Total length $10.3 \mathrm{~mm}$ (paratypes $9.5 \mathrm{~mm}$ ); length of forewing $7.9 \mathrm{~mm}$ (paratypes 7.4-7.8 mm). Color. Black, except anterior tarsus with yellowish second tarsomere (bearing ellipsoid black spot on under side), and yellowish brown tarsomeres 3-5. Anterior tibial spur yellow- 
ish brown, not darkened apically. Wings weakly infuscate, forewing darker along costal margin; veins and pterostigma dark brown. Pubescence. White on head and mesosoma, except blackish hairs on vertex, lateral side of pronotum, upper posterior angle of mesopleuron, upper part of metapleuron and lateral side of propodeum. Legs with white hairs, except mid and hind tarsi with hairs yellowish; outer fringe of foretarsus entirely white. Metasoma with white hairs on discs and apical bands of T1-T3, and on sterna, pale yellow on T4 (including apical band) and bright yellow on T5-T6; erect hairs on T5 golden yellow. Apical bands absent on T1, broadly interrupted medially on T2-T3, and entire on T4-T5. Hairs on disc of scutum long (1.8-3.0x MOD), longer on mesopleuron (2.0-2.5x MOD) and scutellum (1.5-3.5x MOD). Hairs of outer fringe of forebasitarsus 1.8-2.1x apical width of basitarsus. Outer fringe of mid basitarsus with long hairs, basal ones up to $4.5 \mathrm{x}$ apical width of basitarsus. Hairs on disc of T2 2.0-2.5x MOD, on disc of T3 0.8-2.0x MOD. Hairs on S2 forming apical fringe, medially 1.0-1.6x MOD; on S3 shorter, medially 1.0-1.3x MOD. Sculpture. Head with punctures on frons nearly coalescent, on vertex separated by shiny interspaces $0.2-0.5 x \mathrm{PD}$; punctures on disc of scutum irregularly separated by weakly tessellate interspaces $0.2-0.1 \mathrm{x} \mathrm{PD}$; punctures on mesopleuron below hypoepimeral area coalescent; on discs of T2-T3 separated by shiny interspaces 0.5-1.0x PD. Morphology. Inner margin of eyes slightly convergent below, UID $1.13 \mathrm{x}$ LID. Vertex of head moderately broad, distance between lateral ocellus and occipital margin of head 2.2x MOD. Lower margin of mandible with angle on distal third. Apical margin of clypeus with shallow median emargination. Maximum width of gena $0.8 \mathrm{x}$ maximum width of compound eye. Proportions of scape, pedicel and first three flagellomeres 2.9:0.8:1:1.2:1.4; first flagellomere $1.1 \mathrm{x}$ its apical width. Forecoxal spine present, its length 1.0x MOD; basad to spine with group of stiff, decumbent, red setae hidden by long plumose hairs. Anterior basitarsus cylindrical, 3.2x its apical width. Preapical carina of T6 medially with small emargination and irregularly undulate lateral to it. S5, S6, S8, and genital capsule, as in figures $8 \mathrm{Aa}-\mathrm{Da}$.

Female. Total length 10.3-11.5 mm; length of forewing 8.3-8.9 mm. Color. Black, except anterior tibial spur and claws reddish brown. Wings as in male. Pubescence. Head: white on paraocular areas and around antennal sockets, intermixed white and black hairs on lower part of frons and on gena behind middle of eye; other hairs black. White on scutum and scutellum encircling central black hairs, anteriorly on tegula, on metanotum, on postero-lateral angle of propodeum, and dense tuft behind pronotal lobe; other hairs of mesosoma black. Legs with black hairs, except distal part of forefemur with white hairs. Hairs on disc of scutum 1.1-2.4x MOD, longer on mesopleuron (1.9-2.9x MOD). Erect hairs on discs of T1-T2 white (on T2 1.4-2.2x MOD), on discs of T3-T4 (on T3 0.7-1.4x MOD) white to yellowish, with variable extent of black hairs medially, on T4-T5 yellowish to black, on T6 black. Apical bands absent on $\mathrm{T} 1$, interrupted medially on $\mathrm{T} 2-\mathrm{T} 4$, and complete on T5; bands white to yellowish; decumbent pubescence of $\mathrm{T} 6$ dark brown to black, in one specimen with a few intermixed yellowish hairs. Scopa pale ferruginous from S2 to apex of S6. Sculpture. Clypeus and supraclypeal area with dense punctures, separated by shiny interspaces 0.2-0.5x PD; some specimens with narrow, poorly defined median longitudinal impunctate stripe on upper half of clypeus. Acetabular interspace of mandible tessellate. Punctures on most of scutum dense, but on center of disc sparse, separated by tessellate interspaces $0.5-1.5 x$ PD; punctures on mesopleuron below hypoepimeral area nearly coalescent. Discs of terga feebly tessellate; punctures on T3 rounded, but on T4-T5 with posterior margins shallow, poorly defined, appearing as oblong punctures. Morphology. Inner margin of eyes slightly convergent below, UID 1.09x LID. Distance between lateral ocellus and occipital margin of head 1.5x MOD. Clypeus $2.36 \mathrm{x}$ as wide as long; apical margin with median denticle and 2-3 weakly defined denticles on each side of middle. Maximum width of gena 1.03x maximum width of compound eye. Proportions of scape, pedicel and first three flagellomeres 3.2:0.7:1:0.8:1.0; first flagellomere as long as $1.3 \mathrm{x}$ its apical width.

Etymology. The species name is taken from the demonym "puntano" applied to inhabitants of the province of San Luis in Argentina.

Distribution. Argentina, provinces of San Luis and Tucumán.

Material studied. Holotype male, Argentina, Tucumán: Ruta 307 a Tafí del Valle, km 20-30, 1-XI-2004, Compagnucci \& Grismado (MACN). Paratypes: Argentina. San Luis: 1 F, Potrero de Los Funes, \#28646 (MACN). Tucumán: 1 M, 

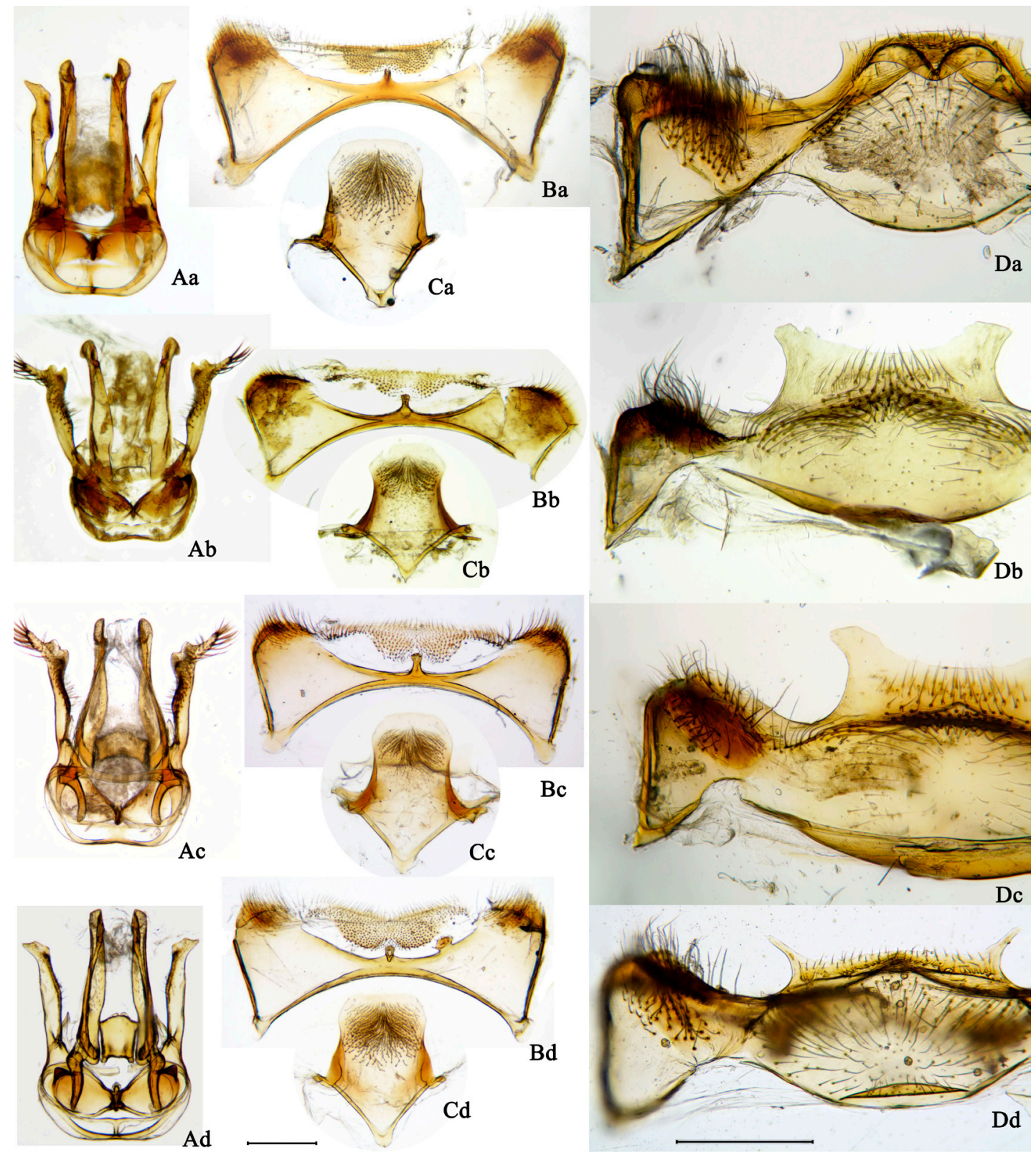

Fig. 6. Terminalia of Megachile (Joergensenella) males. A, genital capsule. B, S5. C, S8. D, S6. Aa-Da, M. bruneriella. Ab-Db, M. fidalgoi. Ac-Dc, M. joergenseni. Ad-Dd, M. lujanense. Scale lines $=500 \mu \mathrm{m}$.

Trancas, San Pedro de Colalao, Arnau - Foerster (SEMC); 1 F, Tucumán, Arnau (SEMC); 1 M, Tucumán, Arnau (MACN).

\section{Megachile (Joergensenella) una Vachal} (Figs. 3F-G, 4F, 4I, 5C-D, 7C, 8Ab-Db, 9, 10C)

Megachile una Vachal, 1909: 15, 17 (Syntypes, males, Argentina, Buenos Aires. Muséum National d'His- toire Naturelle, Paris, not examined). Moure et al., 2007: 1001.

Megachile (Pseudocentron) una: Raw, 2002: 31; 2007: 85. Ascher \& Pickering, 2018.

Diagnosis. This species is distinguished by the blunt, apically blackened anterior tibial spur in both sexes, and the pale vestiture. The female bears on the clypeus and supraclypeal area spe- 
cialized hairs, those on the clypeus with apices sharply bent down and those on the supraclypeal area with wavy apices (Fig. 9). The male is distinguished by its foretarsus with a rufous outer fringe (Fig. 3F-G) and the lack of any marks on the under surface (present in all other species of Joergensenella).

Male. Total length 8.3-11.5 mm; length of forewing 6.8-7.7 mm. Color. Black, with mid and hind legs reddish brown beyond femora and variable extent of ferruginous on legs as follows: palest specimens with foreleg ferruginous beyond trochanter, except dark stripe on outer side of femur, and mid and hind legs with ferruginous distotarsi; darkest specimens with ferruginous restricted to tarsus and apex of tibia of foreleg. Anterior tibial spur yellowish with apical black truncation; anterior basitarsus without black spots on under surface. Wings infuscate, darker along costal margin of marginal cell, and on apex of forewing; veins and pterostigma reddish brown, prestigma and pterostigma paler. Pubescence. White on head and mesosoma, except black on vertex of head, intermixed black and white hairs on center of scutum and scutellum, and variable amount of black hairs on lateral sides of pleurae and propodeum. Hairs on disc of scutum long (0.8-1.6x MOD), longer on mesopleuron (1.3-1.6x MOD) and scutellum (1.3$2.1 \mathrm{x}$ MOD). Legs with white hairs proximally and bright yellowish hairs on tarsi and underside of tibiae, except forebasitarsus with dense outer fringe of rufous hairs (as long as 2.0-2.3x apical width of basitarsus) partly covered dorsally by shorter white hairs. Outer fringe of mid basitarsus with long hairs, basal ones up to $2.5 \mathrm{x}$ apical width of basitarsus. Metasoma with white hairs on discs of T1-T2, other hairs yellowish including apical bands; erect hairs on T5 golden yellow. Apical bands complete on T2-T5. Hairs on disc of T2 1.3-1.6x MOD, on disc of T3 0.6-0.8x MOD. Apical hairs on S2-S3 0.6-0.8x MOD, simple, not forming dense apical fringes. Sculpture. Head with punctures on frons nearly coalescent, on vertex separated by weakly tessellate interspaces 0.2-0.5x PD; punctures on disc of scutum irregularly separated by tessellate interspaces 0.2-1.0x PD; punctures on mesopleuron below hypoepimeral area coalescent; on discs of T2T3 separated by polished interspaces $0.2-0.5 \mathrm{x}$ PD. Morphology. Inner margin of eyes slightly convergent below, UID 1.1x LID. Vertex of head broad, distance between lateral ocellus and occipital margin of head 2.0-2.2x MOD. Lower margin of mandible rounded, not angulate on distal third. Apical margin of clypeus with median emargination, without denticles. Maximum width of gena $0.9 \mathrm{x}$ maximum width of compound eye. Proportions of scape, pedicel and first three flagellomeres 3.3:0.9:1:1.2:1.4; first flagellomere $1.25 \mathrm{x}$ its apical width. Forecoxal spine present, strong, its length 1x MOD; basad to spine with group of stiff, decumbent, red setae hidden by long plumose hairs. Forebasitarsus flattened, $2.6 \mathrm{x}$ its apical width. Preapical carina of T6 medially with small emargination. S5, S6, S8, and genital capsule, as in figures $8 \mathrm{Ab}-\mathrm{Db}$.

Female. Total length 10.5-12.5 mm; length of forewing 7.7-9.0 mm. Color. Black, except anterior tibial spur yellowish with blackened apex, and reddish brown distotarsi. Wings as in male. Pubescence. Head: white on paraocular areas, around antennal sockets and lower part of frons; some specimens with small white patch on gena behind middle of eye; other hairs black. Hairs on clypeus rigid, perpendicular to clypeal surface, with apices bent down at right angles; hairs on supraclypeal area similar, but with wavy apices. Pubescence white on scutum and scutellum (encircling central black hairs) anteriorly on tegula, on metanotum, and dense tufts behind pronotal lobe and above propodeal spiraculum; other hairs of mesosoma including legs, black. Hairs on disc of scutum 1.0-1.6x MOD, longer on mesopleuron (1.6-2.0x MOD). Erect hairs on disc of T1T2 white (on T2 1.3-1.6x MOD), on disc of T3 (0.5-0.7x MOD) dark brown to black, but white in some specimens, on disc of T4-T5 dark brown to black intermixed with yellowish hairs, on T6 with black erect hairs and with varying amounts of white and black appressed hairs. Apical bands white to yellowish, complete on T2-T5. S1, base of S2, and in some specimens apex of S6 with black hairs. Scopa yellowish. Sculpture. Clypeus with dense, deep punctures, regularly separated by shiny interspaces $0.3-0.5 x \mathrm{PD}$, without median longitudinal impunctate stripe; supraclypeal area with transverse impunctate band close to epistomal suture and upper part with punctures similar to those of clypeus. Acetabular interspace of mandible finely tessellate. Punctures on most of scutum close, but on center of disc separated by tessellate interspaces $0.5-1.5 x \mathrm{PD}$; punctures on mesopleuron below hypoepimeral area coalescent. Discs of terga with punctures rounded, on discs of T2-T3 separated by polished interspaces 0.2-0.8x PD. Morphology. Inner margin of eyes slightly convergent below, UID 1.05x LID. 

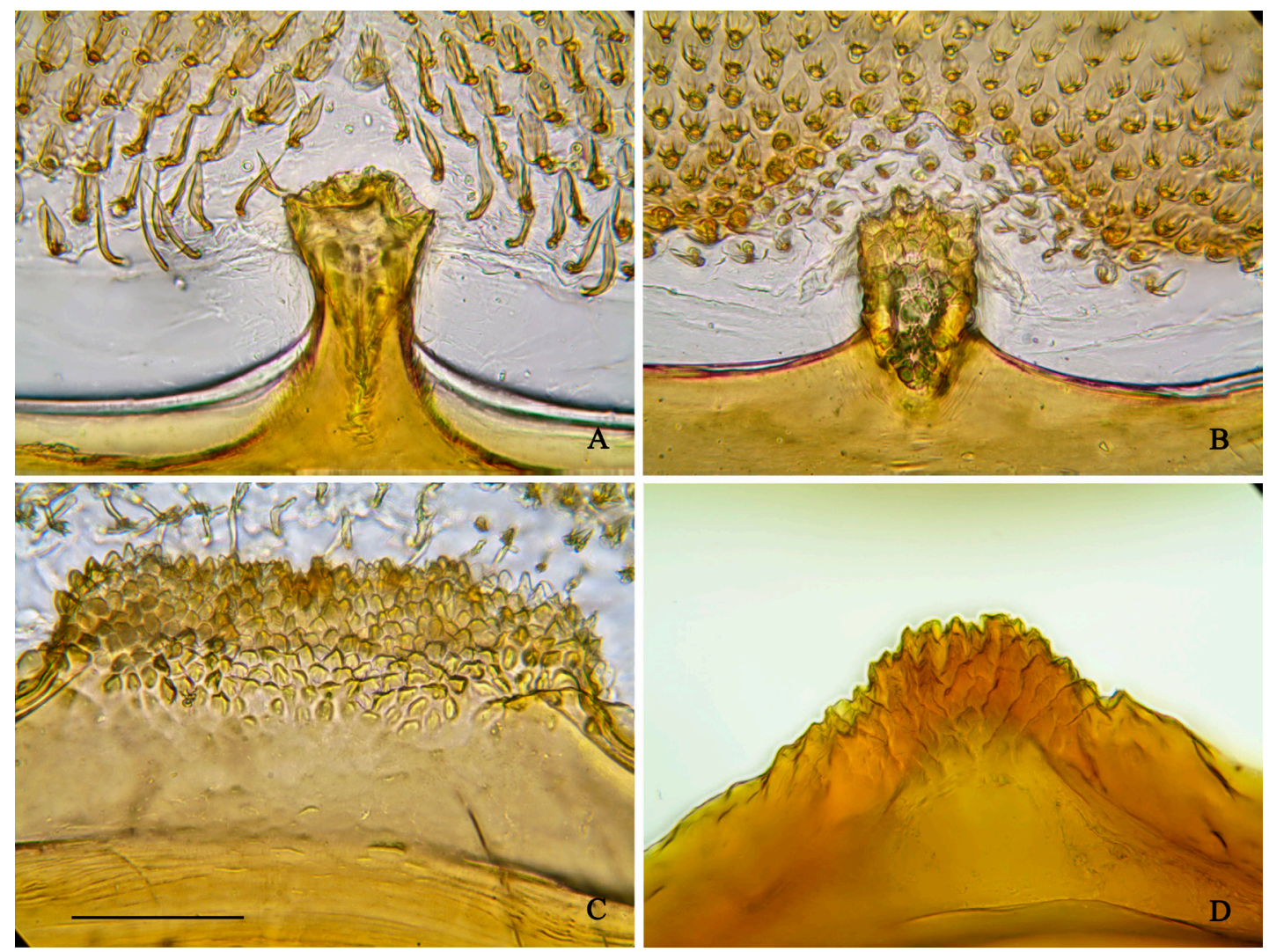

Fig. 7. Megachile (Joergensenella) males, median projection of antecosta of S5. A, M. joergenseni. B, M. lujanense. C, M. una. D, M. yana. Scale line $=100 \mu \mathrm{m}$.

Distance between lateral ocellus and occipital margin of head 2x MOD. Clypeus 2.4x as wide as long; apical margin with small median denticle and 3-4 small denticles on each side of middle. Maximum width of gena 0.9x maximum width of compound eye. Proportions of scape, pedicel and first three flagellomeres 2.9:0.8:1:0.8:1.0; first flagellomere as long as $1.4 \mathrm{x}$ its apical width.

Comments. This is a frequent species in the city of Buenos Aires and surrounding areas. I have not seen the types (unavailable for study), but Vachal's description leaves no doubt about the identity of the species. I have observed the males annoying the females while they were busy collecting pollen from Salvia $s p$. in the garden of the Museo Argentino de Ciencias Naturales, Buenos Aires.

Distribution. Argentina, provinces of Buenos Aires, Córdoba, Corrientes, Entre Ríos, Chaco, and Misiones. Brazil, state of Rio Grande do Sul. Uruguay, department of Río Negro.
Material studied. Argentina. Buenos Aires: 1 F, Cañuelas, 20-I-1919 (MACN); 1 F, Río Sarmiento, Delta del Paraná, XII-1987, A. Oliva (MACN); 4 F, Buenos Aires, 16-XII-2007, 6-I1904, 4-IV-1904, 7-I-1908, J. Brèthes (MACN); 12 M, Buenos Aires, 24-II-1904, 25-III-1904, 4-IV-1904，25-III-1909, J. Brèthes (MACN); 1 F, Bella Vista, 10-I-1903, A. Gallardo (MACN); 1 F, Zelaya, I-1939, H. Hepper (MACN); 1 F, 1 M, Ciudad Buenos Aires, Parque Centenario, 24X-2006, on Salvia sp., A. Roig A. (MACN); 2 M, Hurlingham, INTA Castelar, 4-II-2004, A. Roig A. \& L. Compagnucci (MACN); 1 M, Tigre, Río Luján, Club ACA, 13-X-2002, A. Roig A. (MACN); 3 M, Martínez, Pdo. San Isidro, 15-III-1993, A. Roig A. (MACN); 1 M, San Martín, 16-XI-1919, M. Gómez (MACN); 1 M, Otamendi, 24-I-2000, A. Roig A. (MACN); 1 M, Villa Elisa, II-1955, J. Foerster (SEMC); $1 \mathrm{M}$, Buenos Aires, 20-II-1909 (MLP); 2 M, Pila, depto. Pila, $\left(36^{\circ} 00^{\prime} 15^{\prime \prime} \mathrm{S} 58^{\circ} 08^{\prime} 28^{\prime \prime} \mathrm{W}\right)$ trap nests, emergence dates 19/20-X-2011, J. P. Torretta (FAUBA). Córdoba: 3 F, 3 M, Pizarro, 10-II-1921, Jaeshke (MACN). Corrientes: $1 \mathrm{M}$, 
Arroyo Itaembí, límite Corrientes - Misiones, 20XII-1947, De Carlo (MACN); 5 M, Santa Teresa, P. N. Mburucuyá ( $28^{\circ} 01.233 \mathrm{~S}, 58^{\circ} 02.367 \mathrm{~W}$ ), 5-X2009, N. Veiga (MACN); 3 F, Santa Teresa, P. N. Mburucuyá, 2-V-2008, 17-X-2008, 9-IV-2010, A. Taylor \& N. Veiga (MACN); 5 M, Potrero Tung, P. N. Mburucuyá ( $\left.28^{\circ} 01.233 \mathrm{~S} 58^{\circ} 02.067 \mathrm{~W}\right), 17-\mathrm{X}$ 2009, N. Veiga (MACN). Entre Ríos: 1 M, Parque Nacional Predelta (32응 07.305S 60 37.992W) 16XII-2015, Compagnucci, González V. \& Vossler (MACN). Chaco: 1 F, Capitán Solari, P. N. Chaco $\left(26^{\circ} 53.474 \mathrm{~S} 59^{\circ} 36.245 \mathrm{~W}\right), 26-\mathrm{V}-2008$, A. Taylor \& N. Veiga (MACN). Misiones: 2 M, San Juan, XII-1922, M.Gómez (MACN); 1 F, 7597 (MACN); 1 F, 3 M, 1-XI-1910, 1-I-1911, P. Jörgensen (MLP). Brazil. Rio Grande do Sul: 1 M, Pelotas, 28II-1959, C. M. Biezanko (MACN). Uruguay. Río Negro: 1 F, Menafra, 8-XI-1914 (MACN).

\section{Megachile (Joergensenella) yana n. sp.} (Figs. 3H-I, 4G, 4J, 5E-F, 7D, 8Ac-Dc, 10C)

urn:lsid:zoobank.org:act:2D14C1BC-94CA-4870 -A786-990614ADEF68

Diagnosis. This species, with extensive black vestiture, is the largest in the subgenus. It is allied to $M$. una, with pale vestiture; both species share the blunt, apically blackened anterior tibial spur in both sexes, and the color of the integument and shape of the foretarsus of the male. The male is distinguished from $M$. una, besides the dark vestiture, by the presence of black spots on the underside of the anterior basitarsus and second tarsomere of the male, and the foretarsus with the outer fringe of white hairs with black tips.

Male holotype. Total length $12.0 \mathrm{~mm}$; length of forewing $9.8 \mathrm{~mm}$. Color. Black, except anterior leg with yellowish brown under surface of femur, inner surface of tibia, tibial spur (except apical black truncation) and tarsomeres 3-5; forebasitarsus yellowish with diffuse black spot on under surface basally, and second tarsomere also yellowish with ellipsoid black spot on under side. Wings infuscate, paler towards apex; veins and pterostigma dark brown. Pubescence. Head: white on clypeus and supraclypeal area (with interspersed black hairs), on lower paraocular area, and around antennal insertions; black on remainder of head. Lower margin of mandible with dense basal tuft of black hairs. Mesosoma: with scattered white hairs on anterior and lateral margins of scutum and white hairs on outer surface of forefemur; hairs of outer fringe of forebasitarsus white with black apices; other hairs black. Hairs of metasoma entirely black. Hairs on disc of scutum 0.9-1.7x MOD, longer on mesopleuron (1.7-2.3x MOD) and scutellum (1.22.7x MOD). Hairs of outer fringe of forebasitarsus 1.7-2.0x apical width of basitarsus. Outer fringe of mid basitarsus with long hairs (basal ones up to $2.7 \mathrm{x}$ apical width of basitarsus). Metasoma with lateral apical bands of plumose hairs on T2$\mathrm{T} 4$; hairs on disc of T2 1.1-1.7x MOD, on disc of T3 shorter, 0.6-1.1x MOD; hairs on apex of T5 stiff and simple, not forming band. S2-S4 with dense apical bands of long plumose hairs (on S2 1.5-2.0x MOD medially, 3.8-4.5x MOD laterally). Sculpture. Head with punctures on frons and behind ocelli nearly coalescent, but on ocellocular area irregularly separated by shiny interspaces 0.5-1.0x PD; punctures on center of disc of scutum separated by weakly tessellate interspaces $0.5-1$ $.0 \mathrm{x} \mathrm{PD}$, progressively closer towards lateral and posterior margins; punctures on mesopleuron below hypoepimeral area nearly coalescent; on discs of T2-T3 separated by polished interspaces 1.0-1.5x PD. Morphology. Inner margin of eyes slightly convergent below, UID 1.06x LID. Vertex of head broad, distance between lateral ocellus and occipital margin of head 2.0x MOD. Lower margin of mandible with strong angle on distal third. Apical margin of clypeus crenulate medially. Maximum width of gena $0.8 \mathrm{x}$ maximum width of compound eye. Proportions of scape, pedicel and first three flagellomeres 2.7:0.7:1:1.3:1.3; first flagellomere 1.4x its apical width. Forecoxal spine present, strong, its length 1.15x MOD; basad to spine with group of stiff, decumbent, red setae hidden by long plumose hairs. Anterior basitarsus flattened, 2.3x its apical width. Preapical carina of T6 medially with irregular, denticulate emargination. S5, S6, S8, and genital capsule, as in figures 8Ac-Dc.

Female. Total length $14 \mathrm{~mm}$; length of forewing $10.8 \mathrm{~mm}$. Color. Entirely black, except claws dark reddish brown. Wings as in male. Pubescence. Black, except a few white hairs on frons and on base of antennal scape; apical mandibular brushes ferruginous. Scopa black. Hairs on disc of scutum 1.0-1.5x MOD, longer on mesopleuron (2.5-3.0x MOD). Apical bands of black, plumose hairs complete on T1-T3; on T4 band weaker medially and on $\mathrm{T} 5$ restricted to side; discs of T1T5 with long, erect hairs (1.0-1.3x MOD on T2, 1.5-2.0x MOD on T3); T6 with decumbent, plumose hairs and interspersed erect, simple hairs. Sculpture. Clypeus with dense punctures, regularly separated by shiny interspaces $0.2-0.5 x \mathrm{PD}$, 

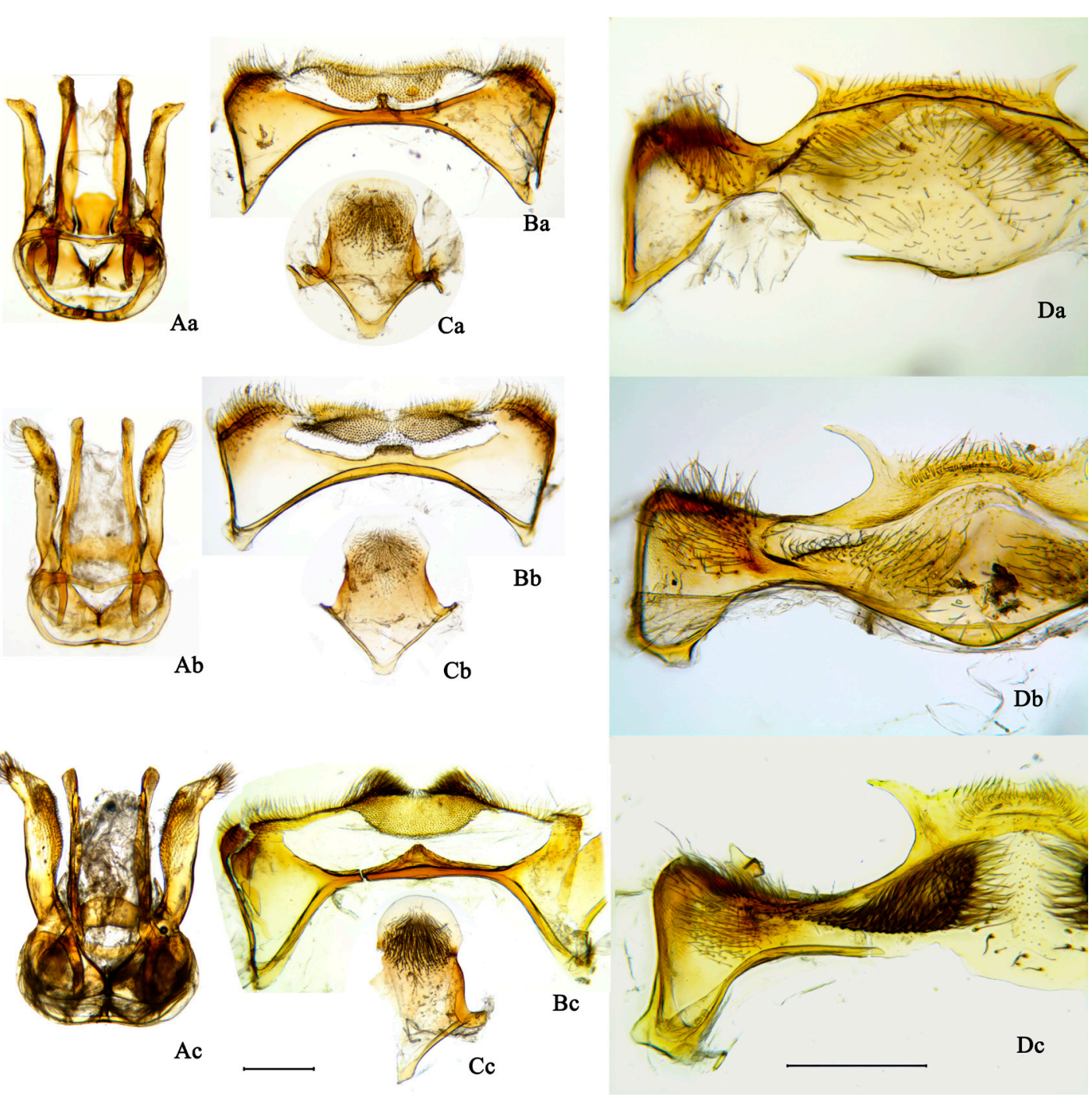

$\mathrm{Ab}$

$\mathrm{Cb}$

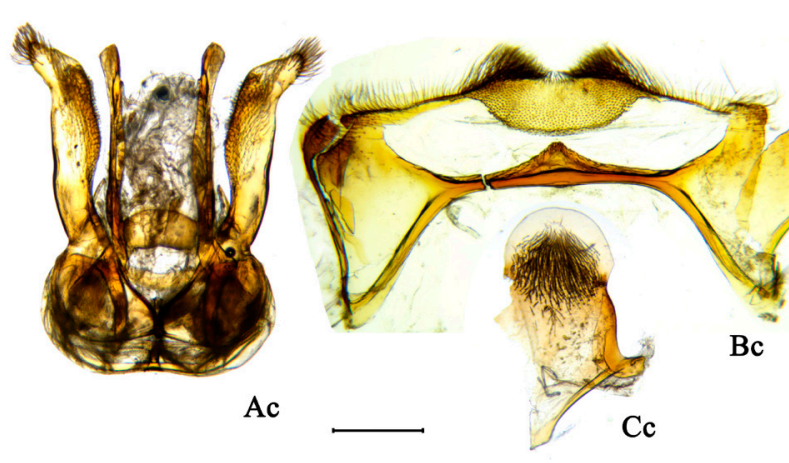

Fig. 8. Terminalia of Megachile (Joergensenella) males. A, genital capsule. B, S5. C, S8. D, S6. Aa-Da, M. puntana. Ab-Db, M. una. Ac-Dc, M. yana. Scale lines $=500 \mu \mathrm{m}$.

without median longitudinal impunctate stripe, contrasting with central and lower portions of supraclypeal area with few scattered punctures. Acetabular interspace of mandible finely tessellate. Punctures on most of scutum close, but on center of disc separated by weakly tessellate interspaces 1-2x PD; punctures on mesopleuron below hypoepimeral area dense, separated by interspaces $0.1-0.5 x$ PD. Discs of terga with punctures deep, on discs of T2-T3 separated by weakly tessellate interspaces $0.5-1.5 x$ PD. Morphology. Inner margin of eyes slightly convergent below, UID 1.1x LID. Distance between lateral ocellus and occipital margin of head 1.6x MOD. Clypeus 2.1x as wide as long; apical margin with median denticle and weakly denticulate on each side of middle. Maximum width of gena $0.9 x$ maximum width of compound eye. Proportions of scape, pedicel and first three flagellomeres 3.2:0.7:1:0.8:0.9; first flagellomere as long as $1.4 \mathrm{x}$ its apical width.

Etymology. The species name, black in Quechua, refers to the black integument and vestiture of this bee.

Distribution. Argentina, province of La Rioja. 
Material studied. Holotype male, Argentina, La Rioja, IX-1930, Lanxano leg., cat. n²5700 (MACN). Paratypes: 2F, $1 \mathrm{M}$, same data as the holotype (MACN).

\section{Megachile in Argentina with specialized facial pollen-harvesting hairs}

One species in the new subgenus, M. una Vachal, has a pollen-collecting device on the face consisting of specialized hairs on the clypeus and the supraclypeal area (Fig. 9). This structure, related to the collection of pollen from nototribic flowers of the families Lamiaceae and Plantaginaceae, is known to occur in many different taxa of bees (Müller 1996a, 1996b). At least ten species of bees have this type of pollen-collecting apparatus in Argentina: three species of Anthidium (Megachilidae, González and Griswold, 2013), two species of Anthophora (Apidae, Brooks, 1988), two species of Zikanapis (Colletidae, Compagnucci, 2006), and the three species of Megachile treated herein: M. (Joergensenella) una, M. (Dasymegachile) schwimmeri Engel, and M. (Cressoniella) boliviensis Friese.

The degree of facial modification varies in the three species. Megachile boliviensis has a convex clypeus and supraclypeal area, $M$. una has a moderately convex clypeus and a weakly convex supraclypeal area, and M. schwimmeri has a weakly convex clypeus and a flat supraclypeal area. The modified hairs on the supraclypeal area reach above to mid level of the antennal sockets in $M$. boliviensis, but these hairs surpass the upper level of the antennal sockets in the other two species. The hairs on the clypeus are gently curved down in $M$. boliviensis, but they are sharply curved down at right angles in $M$. una and M. schwimmeri. In the three species the hairs are distinctly curved down on the clypeus, but on the supraclypeal area they are weakly curved at the apex or have wavy apices. On account of this, it is clear that $M$. boliviensis has the less modified face, and at the opposite end stands $M$. schwimmeri. The degree of modification of $M$. una is closer to that of $M$. schwimmeri than to that of $M$. boliviensis.

\section{Key to Megachile females with modified facial hairs in Argentina}

1.- Upper tooth of mandible pointed. Apex of mandible with outstandingly developed brush of setae on distal end of acetabular groove, well developed brush on distal end of outer

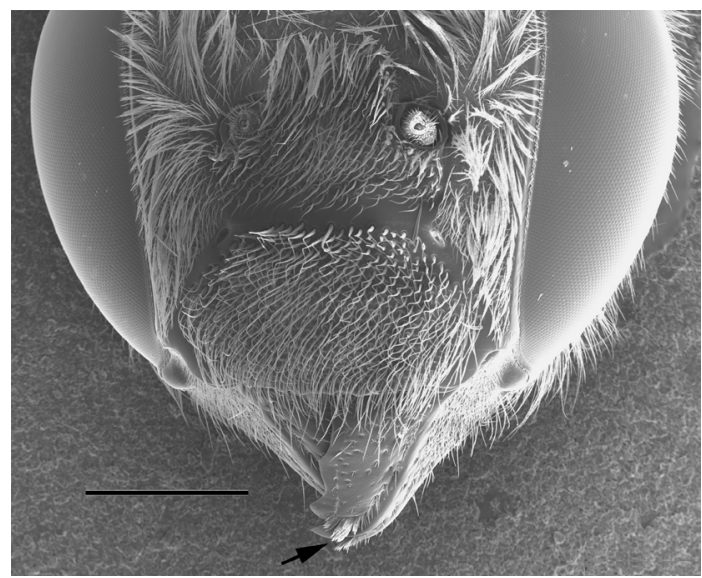

Fig. 9. Megachile (Joergensenella) una, female, face. Arrow: apical brushes of mandible. Scale line $=1 \mathrm{~mm}$.

groove, and small brush on distal end of condylar groove (Fig. 9). M. una

.- Upper tooth of mandible broad, weakly incised (may look truncate in worn specimens). Apex of mandible with brush of setae only on distal end of acetabular groove, other grooves with usual seriate setae. 2

2.- Scopa black. Supraclypeal area flat, with stiff, modified hairs surpassing upper level of antennal sockets. M. schwimmeri

.- Scopa pale, yellowish (basally) to orange (apically). Supraclypeal area convex, with stiff, modified hairs not reaching upper level of antennal sockets. M. boliviensis

\section{M. (Cressoniella) boliviensis Friese}

(Fig. 10D)

Megachile boliviensis Friese, 1916: 340 (Lectotype male, Bolivia, Alpengebiet, Museum für Naturkunde, Berlin, present designation, examined through photographs).

Megachile (Cressoniella) boliviensis: Mitchell, 1934: 302. Raw, 2007: 41.

Diagnosis. The females are distinguished from other species of Cressoniella by the modified hairs on the clypeus and supraclypeal area. Males are distinguished by the extremely dense brush of golden-brown hairs on the metasomal S1, and by the flattened, spiniform projections on the mesothoracic venter in front of the mid coxae.

The male here designated as the lectotype bears a red label "Megachile / LECTOTYPUS / boliviensis / Fritz." Manfredo Fritz studied this speci- 

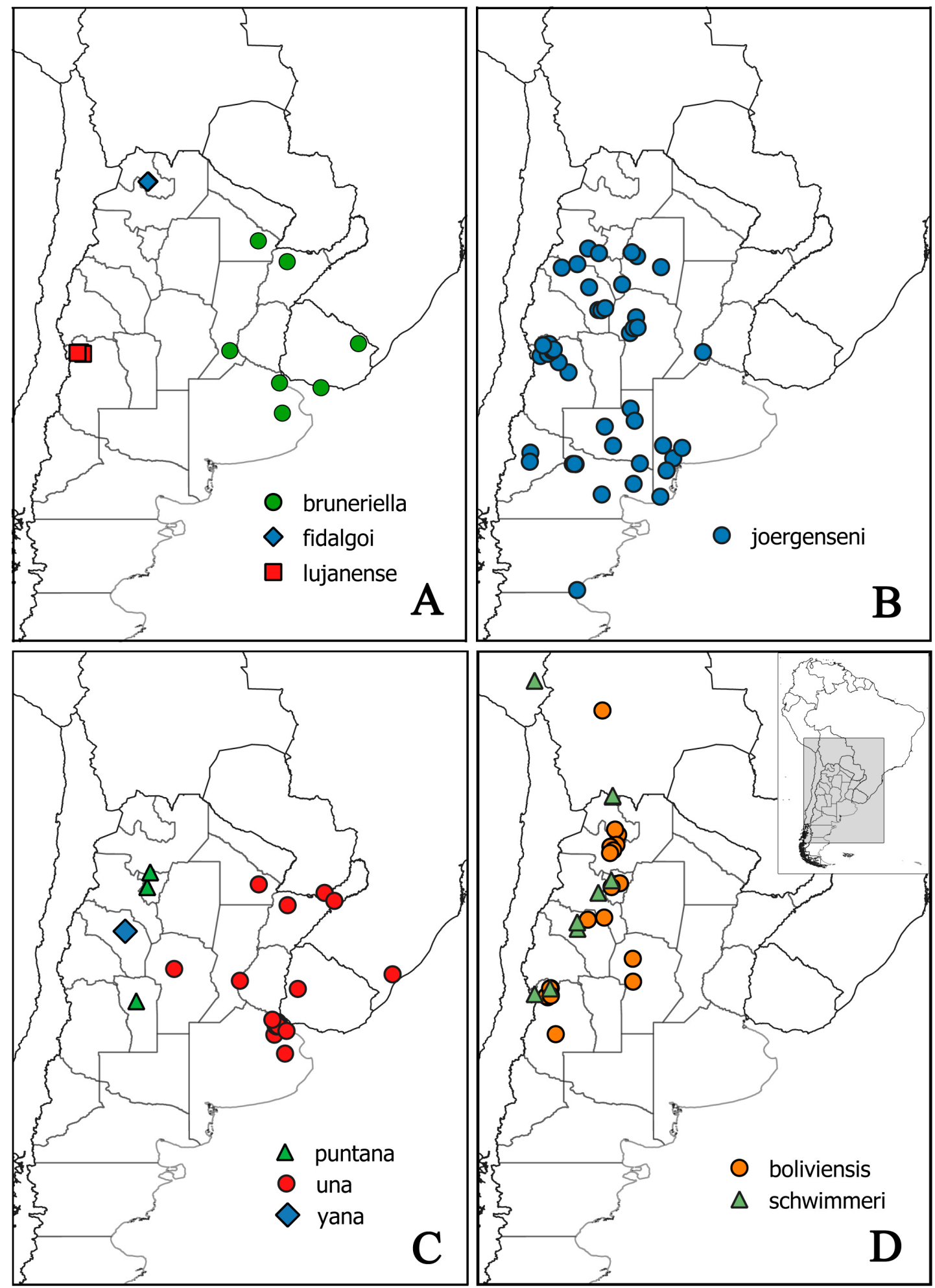

Fig. 10. A-C, distribution maps of Megachile (Joergensenella) species. D, distribution map of M. (Cressoniella) boliviensis and M. (Dasymegachile) schwimmeri. 
men in 1991, but never published the lectotype designation.

Distribution. Argentina, provinces of Córdoba, Jujuy, Mendoza, Salta, and Tucumán. Bolivia, department of Cochabamba.

Material studied. Argentina. Catamarca: 2 M, Concepción, II-1928, M. Gómez, no21.924 (MACN). Córdoba: 1 F, 1 M, Sierras de Córdoba, 26-III-1930 (MACN); 1 F, El Sauce, Departamento Calamuchita, XII-1938, M.J. Viana (MACN); 1 M, Los Cocos, E. Blanchard (MACN); 1 M, prov. Córdoba, IV-1928, E. Blanchard (MACN). Jujuy: $1 \mathrm{~F}$, Travi (MACN); $1 \mathrm{M}$, El Volcán (MACN). La Rioja: 2 M, Anillaco, 1-6-XI-2011, Roig A., González V. \& Compagnucci, ex Prosopis sp. (MACN).Mendoza:1F,Potrerillos, C.Spegazzini, no10094 (MACN); 1 M, Potrerillos, 18-I-1985, A. Roig A. (MACN); 1 M, Potrerillos, Arroyo Tres Saltos, 19-XII-2002, G. Debandi (IADIZA); 1 M, 2 F, Cacheuta, no7845 (MACN); 3 F, San Rafael, El Nihuil, 24-I-2012, J.P. Torretta, ex Baccharis sp. (MACN); 4 F, 1 M, Villavicencio, Sitio V1, $32.523139^{\circ} \mathrm{S}$ 68.955111ํㅡ, 18/21-XI-2008, 21-X2011, 11-XI-2011, D. Vázquez, N. Chacoff \& J. Dorado (IADIZA, MACN); 6 F, 5 M, Villavicencio, Sitio V4, 32.538722 ${ }^{\circ} \mathrm{S} 68.9939611^{\circ} \mathrm{o}$, 31-X-2008, 2/17-XII-2008, 4-X-2011, 21-X-2011, 20-XI-2011, D. Vázquez, N. Chacoff \& J. Dorado (IADIZA, MACN); 1 F, Godoy Cruz, Puesto Chambón, 1-XII-1995, G. Debandi (IADIZA). Salta: 1 F, ciudad Salta, Campus Universidad Católica, IV-1973, A. Roig A. (MACN); 1 F, El Alisal, III1993, M. Fritz (MACN); 1 F, El Mollar, 27-XI2003, B. Schlumpberger, ex Echinopsis ancistrophora (MACN); 1 F, Escoipe, 12-XII-2003, B. Schlumpberger, ex Echinopsis ancistrophora (MACN). Tucumán: 1 F, Tucumán, I-1914, Girard (MACN); 1 M, 12 km W Lules, 17-XI-1993, A. Roig A. (MACN); 1 M, Ruta provincial 307 a Tafí del Valle, km 20-30, 1-XI-2004, Compagnucci \& Grismado (MACN). Bolivia. Cochabamba, 8-XII-1946, R. Zischka (MLP).

\section{M. (Dasymegachile) schwimmeri Engel}

(Fig. 10D)

Cressoniella (Chaetochile) golbachi Schwimmer in Mitchell, 1980: 87-91, figs. 56-57 (Holotype female, La Quiaca, Jujuy, Argentina, 9-111960, R. Golbach, National Museum of Natural History, USA, not examined).

Megachile (Dasymegachile) golbachi: Michener, 2000: 555. (nom. preoc. in Megachile, not
Megachile golbachi Schletterer, 1891).

Megachile (Dasymegachile) mitchelli Raw, 2004: 2, nom. nov. for Megachile golbachi (Schwimmer). Moure et al., 2007: 964. (nom. preoc. in Megachile, not Megachile mitchelli Gupta, 1989.

Megachile (Chaetochile) mitchelli: Durante and Abrahamovich, 2006: 105 (females, not the males). Raw, 2007: 26.

Megachile (Dasymegachile) schwimmeri Engel, 2017: 3, nom. nov. for Megachile mitchelli Raw. Ascher \& Pickering, 2018.

Megachile (Chaetochile) schwimmeri: González et al. 2019: 95.

Diagnosis. The females are readily recognized by the flattened face with modified hairs on the clypeus and the supraclypeal area. The male also has a flattened frons, depressed well below the level of the compound eyes. Both sexes have a gibbous scutellum. The male mandible is elongate, with a truncate, somewhat incised second tooth, close to the first tooth and removed from the upper tooth, which is right angular (Schwimmer, fig. 46 in Mitchell, 1980). This type of mandible is distinctive for M. schwimmeri among Argentinean Dasymegachile, except for males of the species treated by Durante and Abrahamovich (2006) as M. schwimmeri, the mandible of which is quite similar.

Durante and Abrahamovich (2006) redescribed in detail the females of $M$. schwimmeri, but they misidentified the males. This is evident when comparing their drawings of male terminalia with those of Schwimmer (in Mitchell, 1980, p. 91). The male specimens from Jujuy cited by Durante and Abrahamovich correspond to a different, probably unnamed, species of Dasymegachile. These specimens have the anterior tarsus with a white outer fringe of hairs, and the apical margin of T6 has broad, trapeziform paramedian projections (Durante and Abrahamovich, 2006: figure 11). Megachile schwimmeri is characterized by the anterior tarsus with black hairs not forming an outer fringe, and the apex of T6 has small, pointed paramedian projections.

The record of $M$. schwimmeri for Rio Grande do Sul, Brazil (Viana \& Alves dos Santos, 2002; Silveira et al. 2002, as M. golbachi) is most probably wrong and may correspond to $M$. una. In Argentina $M$. schwimmeri is not known to occur outside the Andean range, from moderate to high altitudes.

Distribution. Argentina, provinces of 
Catamarca, Jujuy, Mendoza, La Rioja, and Tucumán. Bolivia, department of Potosí. Perú, department of Puno.

Material studied. Argentina. Jujuy: 1 F, La Quiaca, I-1943, B. Cipolletti (MLP); 1 F, Barrios, La Quiaca, 13-II-1958, Torres-Ferreyra (MLP); $1 \mathrm{~F}$, La Quiaca, 3400 m, 1-II-1949, A. Martínez (MLP). Mendoza: $1 \mathrm{~F}$, entre Punta de Vacas y Los Horcones (MACN); 1 M, Villavicencio, Sitio V4, 32.538722으 $68.9939611^{\circ} \mathrm{W}, 21-\mathrm{X}-2011$, D. Vázquez, N. Chacoff \& J. Dorado, ex Salvia giliesii (MACN). La Rioja: 1 F, Nonogasta, XII2927/II-1928, M. Gómez (MACN); 1 F, no locality (MACN); 1 M, Famatina, camino mina La Mexicana, 2846 m, 27-I-2006, Compagnucci, Ojanguren \& Piacentini (MACN). Tucumán: 1 F, El Sunchal, 26-XI-2008, Ortega-Báez, ex Echinopsis schickendantzii (MACN). Bolivia. Potosí: 1 F, 4 M, Villazón, 7-I-1988, L. Moffatt (MACN).

\section{ACKNOWLEDGEMENTS}

I am grateful to two anonymous reviewers for their useful comments on the manuscript. This research was funded by the Agencia Nacional de Promoción Científica y Tecnológica, Argentina, PICT 2016-3185.

\section{LITERATURE CITED}

Ascher, J. \& J. Pickering. 2018. Discover Life bee species guide and world checklist (Hymenoptera: Apoidea: Anthophila). Available from: http://www. discoverlife.org/mp/20q?guide=Apoidea_species (accessed 30 June 2019)

Brooks, R. W. 1988. Systematics and phylogeny of the anthophorine bees. University of Kansas Science Bulletin 53: 436-575.

Cockerell, T. D. A. 1917. Descriptions and records of bees. LXXVI. Annals and Magazine of Natural History (8) 20: 235-241.

Cockerell, T. D. A. 1919. Bees in the collection of the United States National Museum. 3. Proceedings of the United States National Museum 55: 167-221.

Compagnucci, L. A. 2006. Dos especies nuevas de Zikanapis Moure de la Argentina, con setas modificadas en el clípeo (Hymenoptera: Apoidea: Colletidae). Revista del Museo Argentino de Ciencias Naturales, n.s. 8: 87-94.

Durante, S. P. \& A. H. Abrahamovich. 2006. Redescription of Chaetochile as subgenus of Megachile (Hymenoptera, Megachilidae). Transactions of the American Entomological Society 132:103-109.

Engel, M. S. 2017. Replacement names for bees in the tribe Megachilini. Journal of Melittology 70: 1-5.
(Hymenoptera: Megachilidae)

Friese, H. 1908. Die Apidae (Blumenwespen) von Argentina nach der Reisenergebnissen der Herren A.C. Jensen-Haarup und P. Jörgensen in den Jahren 1904-1907. Flora og Fauna 1908: 1-111.

Friese, H. 1916. Zur Bienenfauna von Costa Rica. Stettiner Entomologische Zeitung 77: 287-348.

González, V. H. \& T. L. Griswold. 2013. Wool carder bees of the genus Anthidium in the Western Hemisphere (Hymenoptera: Megachilidae): diversity, host plant associations, phylogeny, and biogeography. Zoological Journal of the Linnean Society 168: 221-425.

González, V. H., T. L. Griswold \& M. S. Engel. 2018. South American Leaf-Cutter Bees (Genus Megachile) of the Subgenera Rhyssomegachile and Zonomegachile, with Two New Subgenera (Hymenoptera: Megachilidae). Bulletin of the American Museum of Natural History 425: 1-73.

González, V. H., G. T. Gustafson \& M. S. Engel. 2019. Morphological phylogeny of Megachilini and the evolution of leaf-cutter behavior in bees (Hymenoptera: Megachilidae). Journal of Melittology 85: 1-123.

Jensen Haarup, A. C. 1908a. Biological researches amongst the Argentine bees with special reference to flowers they visit. Flora og Fauna 1908: 95-107.

Jensen-Haarup, A. C. 1908b. Hoffmanseggia falcaria, Cav., and its visitors amongst bees. Flora og Fauna 1908: 108-111.

Jörgensen, P. 1909. Beobachtungen über Blumenbesuch, Biologie, Verbreitung usw. der Bienen von Mendoza (Hym.). Deutsche Entomologische Zeischrift 1909: 211-227.

Jörgensen, P. 1912a. Revision der Apiden der Provinz Mendoza, Republica Argentina (Hym.). Zoologische Jahrbücher, Abteilung für Systematik 32(2): 89162.

Jörgensen, P. 1912b. Los crisídidos y los himenópteros aculeados de la provincia de Mendoza. Anales del Museo Nacional de Buenos Aires 22: 267-338.

Michener, C. D. 2000. The bees of the world. Johns Hopkins University Press, Baltimore, USA, xiv + $913 \mathrm{pp}$.

Michener, C. D. 2007. The bees of the world, 2nd ed. Johns Hopkins University Press, Baltimore, USA, xvi $+953 \mathrm{pp}$.

Mitchell, T. B. 1930. A contribution to the knowledge of Neotropical Megachile with descriptions of new species (Hymenoptera: Megachilidae). Transactions American Entomological Society 56: 155-305.

Mitchell, T. B. 1934. A revision of the genus Megachile in the Nearctic region. Part I. Classification and descriptions of new species (Hymenoptera: Megachilidae). Transactions of the American Entomological Society 59: 295-361.

Mitchell, T. B. 1936. A revision of the genus Megachile in the Nearctic region. Part IV. Taxonomy of subgenera Xanthosarus, Phaenosarus, Megachiloides and Derotropis (Hymenoptera: Megachilidae). Transactions of the American Entomological Society 62: 117-157, pl. VIII-XI. 
Mitchell, T. B. 1937. A revision of the genus Megachile in the Nearctic region. Part V. Taxonomy of subgenus Xeromegachile (Hymenoptera: Megachilidae). Transactions of the American Entomological Society 62: 323-332, pl. XXII-XXVI.

Mitchell, T. B. 1943. On the classification of Neotropical Megachile (Hymenoptera: Megachilidae). Annals Entomological Society America 36: 656-671.

Mitchell, T. B. 1980. A Generic Revision of the Megachiline Bees of the Western Hemisphere. North Carolina State University, Raleigh, USA, 95 pp.

Moure, J. S., G. A. R. Melo \& A. DalMolin. 2007. Megachilini Latreille, 1802. pp. 917-1001 In: Catalogue of bees (Hymenoptera, Apoidea) in the Neotropical region (eds. J. S. Moure, D. Urban \& G. A. R. Melo). Sociedade Brasileira de Entomologia, Curitiba.

Müller, A. 1996a. Convergent evolution of morphological specializations in central European bee and honey wasp species as an adaptation to the uptake of pollen from nototribic flowers. Biological Journal of the Linnean Society 57: 235-252.

Müller, A. 1996b. Host plant specialization in western palearctic anthidiine bees. Ecological Monographs 66: 235-257.

National Museum of Natural History, Smithsonian Institution. https://collections.nmnh.si.edu/search/ento/ (accessed 30 June 2019)

Raw, A. 2002. New combinations and synonymies of leafcutter and mason bees of the Americas. Zootaxa 71: 1-43.

Raw, A. 2004. Nomenclatural changes in leafcutter bees of the Americas: Megachile Latreille 1802 (Hymenoptera; Megachilidae). Zootaxa 766: 1-4.

Raw, A. 2006. A new subgenus and three new species of leafcutter bees, Megachile (Austrosarus)
(Hymenoptera, Megachilidae) from central Brazil. Zootaxa 1228: 25-34.

Raw, A. 2007. An Annotated Catalogue of the Leafcutter and Mason Bees (Genus Megachile) of the Neotropics. Zootaxa 1601: 1-127.

Roig-Alsina, A. 2019. El subgenénero Chelostomoides en Argentina (Hymenoptera: Megachilidae: Megachile). Revista de la Sociedad Entomológica Argentina 78(3): 22-25.

Schrottky, C. 1913. La distribución geográfica de los himenópteros argentinos. Anales de la Sociedad Científica Argentina 75: 225-286.

Schrottky, C. 1920. Himenópteros nuevos o poco conocidos sudamericanos. Revista Museu Paulista 12 (2): 179-227.

Silveira, F. A., G. A. R. Melo \& E. A. B. Almeida. 2002. Albelhas Brasileiras, Sistemática e Identificação. Belo Horizonte, Brasil, 251 pp.

Toro, H. \& M. Fritz. 1991. Contribución al conocimiento de Dasycoelioxys Mitchell. Acta Entomologica Chilena 16: 69-80.

Trunz, V., L. Packer, J. Vieu, N. Arrigo \& C. J. Praz. 2016. Comprehensive phylogeny, biogeography and new classification of the diverse bee tribe Megachilini: Can we use DNA barcodes in phylogenies of large genera? Molecular Phylogenetics and Evolution 103: 245-259.

Vachal, J. 1909. Espèces nouvelles ou litigieuses d'Apidae. Revue d'Entomologie, Caen 28: 5-72.

Viana B. F. \& I. Alves dos Santos. 2002. Bee diversity of the coastal sand dunes of Brazil. p.135-153, In: Pollinating Bees - The Conservation Link Between Agriculture and Nature (eds. P. Kevan \& V. L. Imperatriz Fonseca). Ministry of Environment, Brasilia.

Doi: 10.22179/REVMACN.22.663

Recibido: 5-XI-2019

Aceptado: 10-IV-2020 